DOE/PO-0058

\title{
New England
}

\section{Electricity Supply Outlook}

Summer 1998 - and Beyond

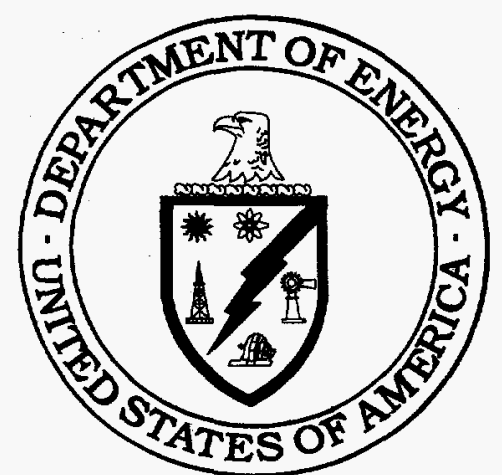

July 1998

OASTRIUUTION OF THS DOCLMENT is URUHATED ph

U.S. Department of Energy

Office of Policy and International Affairs
RECEIVED

AUG $17\{998$

OSTI

MASTER 
DOE/PO-0058

\section{New England}

\section{Electricity Supply Outlook}

Summer 1998 - and Beyond

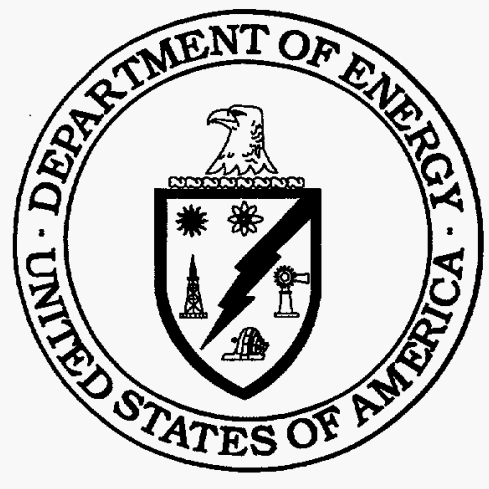

July 1998

U.S. Department of Energy

Office of Policy and International Affairs

Washington, D.C. 20585 


\section{DISCLAIMER}

This report was prepared as an account of work sponsored by an agency of the United States Government. Neither the United States Government nor any agency thereof, nor any of their employees, makes any warranty, express or implied, or assumes any legal liability or responsibility for the accuracy, completeness, or usefulness of any information, apparatus, product, or process disclosed, or represents that its use would not infringe privately owned rights. Reference herein to any specific commercial product, process, or service by trade name, trademark, manufacturer, or otherwise does not necessarily constitute or imply its endorsement, recommendation, or favoring by the United States Government or any agency thereof. The views and opinions of authors expressed herein do not necessarily state or reflect those of the United States Government or any agency thereof. 


\section{DISCLAIMER}

Portions of this document may be illegible in electronic image products. Images are produced from the best available original document. 


\section{New England Electricity Supply Outlook Summer 1998 -- and Beyond}

\section{EXECUTIVE SUMMARY}

New England is in the third summer of a protracted electricity supply shortage that began with the shutdown of a substantial quantity of nuclear generating capacity, particularly the 2,630 megawatts (MW) from the three Millstone units located in Connecticut and owned and operated by Northeast Utilities. This report was prepared in response to a request from Senator Christopher Dodd and Senator Joseph Lieberman, both of Connecticut, that the Department of Energy provide an update to its June 1997 report, New England Electricity Supply Outlook, Summer 1997 -- and Beyond, which examines measures that might be taken to ease the supply shortage, particularly measures to relieve transmission constraints that restrict the import of electricity into Connecticut.

In the interval since the 1997 report, three changes have occurred in the region's overall electric supply context that are particularly significant:

1. The Millstone 3 nuclear unit (1,150 MW) has been put back into service at full capacity.

2. Electricity demand is higher, due primarily to regional economic growth. The region's projected 1998 peak demand is $22,100 \mathrm{MW}, 1,531 \mathrm{MW}$ higher than the region's 1997 peak.

3. Many new additions to the region's generating capacity have been announced, with projected completion dates varying between 1999 and 2002. If all of the announced projects were completed -- which appears unlikely -- the total additions would exceed $25,000 \mathrm{MW}$. A small number of new transmission projects have also been announced.

\section{CONCLUSIONS AND RECOMMENDATIONS FOR THE SUMMER OF 1998}

\section{Conclusions}

1. The regional independent system operator, ISO New England, and its member entities have made systematic efforts to deal with the region's electricity supply problems for this summer. No indications have been found that significant additional measures of a practical and short-term nature were not considered or investigated. Experience gained over the past two years has enabled ISO New England officials to develop a state-of-the- 
art, well-organized response mechanism that enables them to take all available measures to meet demand requirements while minimizing impacts upon customers.

2. The major factor impacting the New England summer 1998 capacity situation is an expected increase in consumer demand, largely attributable to continued economic growth in the region. In order to meet this increased demand, New England utilities have entered into an unprecedented number of firm energy contracts for imports over the New York transmission lines. As a result, the region will be more reliant on imported power to meet day-to-day needs.

3. The organizational change from the New England Power Pool (NEPOOL) to ISO New England has had no apparent impact on the reliability of the region's electricity infrastructure. The officials at ISO New England show every indication that they will continue NEPOOL's strong commitment to ensuring reliability.

4. Barring some combination of unusual circumstances, the region's electricity supplies are likely to be sufficient to avoid serious disruptions, though certainly not ample. Recent developments -- especially the restart of Millstone unit 3 -- have significantly increased the likelihood that the region will be able to meet summer demand with little impact on customers. However, it is important to recognize that if the regional supply system experiences a high level of unplanned generation or transmission outages at the time demand peaks in a normally hot summer, the system might need to invoke some of the demand-reducing measures in Operating Procedure \#4 (OP-4) in order to maintain a balance between supply and demand. Furthermore, it is possible that if the system experiences particularly adverse conditions, such as additional unplanned outages, perhaps in combination with abnormally hot weather, ISO New England could be forced to invoke Operating Procedure \#7 (OP-7), under which load is reduced to the extent required through feeder rotation and load shedding. OP-4 and OP-7 are special operating procedures implemented by ISO New England in the event of an actual capacity shortfall in order to maintain the system's reliability.

5. Despite the utilities' preparations, combinations of adverse conditions may occur. If so, the actions planned under OP-4 and OP-7 should be understood by those affected not as privations but rather as an important safety net. Their use, when conditions warrant, is essential to protect the region from a broader and much more long-lasting outage that could result if the regional electric system were allowed to "crash" as opposed to being brought to a "controlled landing."

6. Successful implementation of OP-4 and OP-7, if needed, will depend on thorough preparation by ISO New England and its member entities, including the development and testing of mechanisms for informing and coordinating with government agencies, the media, and the general public. ISO New England and CONVEX have made major strides 
in this area over the last two years and, as a result, a well-organized communication network is now in place for the 1998 summer peak period.

7. ISO New England and its predecessor NEPOOL have never had to employ OP-7, and over the past decade the conditions requiring the use of OP-4 have arisen unevenly across the region. This means that people in some areas are probably more familiar with the procedures than others. In these circumstances, it is important for ISO New England and its members to continue to institute suitable tests and drills related to these procedures, to review methodically any actual applications of the procedures for "lessons learned," and finally, to take actions as appropriate to follow through on lessons learned.

\section{Recommendations}

1. ISO New England and its members should continue to take steps to ensure their readiness to implement OP-4 and OP-7 if needed. These actions should include appropriate tests or drills and review of any actual application of the procedures for lessons learned.

2. ISO New England should take steps to share their experiences in dealing with capacity shortages with other regional power systems within the Northeast Power Coordinating Council (NPCC) and with the industry at large through the North American Electric Reliability Council (NERC).

3. ISO New England and its members should continue to maintain their communication network and support customer outreach and education about the energy advisory system and the potential need to implement operating procedures.

4. ISO New England should continue to closely monitor the emerging developments in the region's generating capacity. In particular, they should confirm that Millstone unit 3 and Seabrook $(1,160 \mathrm{MW})$ continue to have a smooth transition back into service, that actions continue to support the restart of Bridgeport Harbor unit 3 (375 MW) and Millstone unit $2(870 \mathrm{MW})$, and that progress continues towards the completion of Phase One of the Bridgeport Energy project (230 MW).

\section{ELECTRICITY SUPPLY OUTLOOK FOR NEW ENGLAND FOR THE SUMMER OF 1999 AND BEYOND}

Electricity supply in New England has already increased significantly with the restart of Millstone unit 3. Additional restarts at Millstone unit 2 and Bridgeport Harbor unit 3 and the availability of the new state-of-the-art Bridgeport Energy gas-fired power plant -- all of which the industry anticipates will occur this year -- will further augment New England's available resources. In addition, the prospect of competitive wholesale and retail electric markets in the 
region appears to be driving a dramatic response by energy suppliers to the recent shortages. A large amount of new generating capacity is now projected to come on line between 1999 and 2002. Thus, with a range of additional supply options on the horizon, the long-term outlook for reliable, ample, and economically-priced electricity supplies in New England appears good. 


\section{PURPOSE AND SCOPE OF THIS REPORT}

The purpose of this report is to respond to a request from Senator Christopher Dodd and Senator Joseph Lieberman that the Department of Energy (DOE) provide an update to its June 1997 report, New England Electricity Supply Outlook, Summer 1997 - and Beyond (DOE/PO-0054). Specifically, this report revisits the following issues:

- Transmission constraints that restrict the import of electricity into New England and Connecticut, and may adversely affect the availability of safe, secure, and reliable electricity supplies in Connecticut; and

- Whether additional steps can be taken in the near term to ease these constraints so as to help ease potential electricity shortages in New England and Connecticut during the summer of 1998.

As with the 1997 report, this document examines and discusses a wide range of measures that have been considered across the region such as increasing indigenous generation capacity, tapping generation sources external to the region via transmission, and load management actions. It examines the near-term steps that have been taken or are still in process to help ease the supply problem for the summer of 1998 and also discusses some possible longer-term measures.

The report is divided into the following sections:

- Section I describes the New England electricity supply system in physical and organizational terms, including its transmission ties to adjacent systems.

- Section II discusses the electricity supply outlook for the summer of 1998 , both for the New England region and for the state of Connecticut, and summarizes the short-term actions that have already been taken or are being taken by the region's utilities and ISO New England in preparation for the summer. The section closes with some conclusions and recommendations about the preparations that ISO New England and its member entities have made for the summer of 1998.

- Section III concludes with a brief discussion of the regional electricity supply issues for the summer of 1999 and beyond, including transmission-related options. 


\section{DESCRIPTION OF THE NEW ENGLAND ELECTRICITY SUPPLY SYSTEM}

\section{THE ROLE OF ISO NEW ENGLAND AND NEPOOL}

Management of the bulk-power generation and transmission systems on behalf of the electric companies in the six-state New England region (Connecticut, Maine (except the northern-most portion), Massachusetts, New Hampshire, Rhode Island, and Vermont) is the responsibility of the independent system operator, ISO New England. Regulated by the Federal Energy Regulatory Commission (FERC), ISO New England's primary mission is to ensure the safe, secure and reliable operation of the region's electricity systems in accordance with established reliability criteria. In addition, ISO New England will have responsibility for administering the real-time competitive wholesale marketplace that is scheduled to go into operation by the end of 1998 .

ISO New England was established as a not-for-profit, private corporation on July 1, 1997. The ISO was formed by transferring staff and equipment from the New England Power Pool (NEPOOL), a voluntary association of electric utilities in New England. NEPOOL was established in 1971 as a single integrated system responsible for the central dispatch, coordination, and monitoring of all generation and high-voltage transmission facilities in the region. In many ways, NEPOOL, with its state-of-the-art control center, already functioned like an ISO. Its operation enabled central dispatch of the bulk-power system using the most economic generating and transmission equipment available at any given time to match the electric load of the region. By supporting the establishment of ISO New England, NEPOOL members created an organization with enhanced independence that meets FERC requirements for ensuring fair and open access to the region's transmission system in the emerging competitive electricity marketplace.

NEPOOL will continue to exist as the entity representing traditional utilities, as well as other companies participating in New England's competitive electricity marketplace. ISO New England has a services contract with NEPOOL to operate the bulk-power system and to administer the wholesale marketplace.

ISO New England was created with an independent board of directors to oversee an organization made up of 150 people. The ISO New England staff is made up largely of former NEPOOL employees with over 25 years of experience in dispatching the bulk-power system for New England; maintaining system security and reliability; and forecasting short and long-term electricity demand. The staff is divided into two groups: ISO New England employees working in the Systems Operations and Reliability area are responsible for the daily dispatch of electricity resources and maintaining the reliability of the bulk-power system. This area is also responsible for short-term and long-term demand forecasting and reliability planning. The second area is Market Operations, charged with overseeing the functioning of the wholesale electricity marketplace to ensure the development of cost-effective, competitive markets for bulk-power. 
Ensuring the reliability of the region's bulk-power system is one of ISO New England's most important responsibilities. The ISO New England Reliability Criterion inherited from NEPOOL states that, "each area's resources will be planned in such a manner that after due allowance for scheduled maintenance, forced and partial outages, interconnections with neighboring areas, and available operating procedures, the probability of disconnecting non-interruptible customers due to a resource deficiency, on the average, will be no more than once in ten years." In addition, provisions are included in the agreement between ISO New England and NEPOOL guaranteeing that the power system will continue to be operated in accordance with the standards of the North American Electric Reliability Council (NERC).

ISO New England operates in part through four satellite dispatch centers: CONVEX (Connecticut and portions of western Massachusetts), Maine, PSNH (New Hampshire), and REMVEC (Rhode Island, eastern Massachusetts, and Vermont). ISO New England itself is responsible for coordinating maintenance schedules across the region, to ensure that a sufficient and relatively economic mix of generating units is available at all times. It also plans on a dayahead basis for the dispatch of the system, so as to ensure that as demand rises and falls, the region is always operating the most economically efficient set of available generating units. The satellite dispatch centers execute the dispatch plan, and may propose modifications to the plan if needed to ensure reliability at the local level. There is some functional redundancy between ISO

New England and the satellites, but this is by design and it enhances the safety and security of the system.

\section{COORDINATION WITH OTHER POWER POOLS}

To aid in maintaining reliable and economically efficient service, NEPOOL (as operated by ISO New England) is one of five subregions of the Northeast Power Coordinating Council (NPCC). NPCC, in turn, is one of ten regional reliability councils throughout the U.S., Canada and portions of Mexico that form NERC. The other NPCC subregions are the New York Power Pool, and three areas in Canada (Ontario, Quebec, and the Maritimes).

ISO NEW ENGLAND'S TRANSMISSION NETWORK (including ties to adjacent pools)

ISO New England coordinates the operation of more than 7,000 miles of transmission lines connecting 330 generating plants representing $23,000 \mathrm{MW}$ of installed capacity. The main skeleton of this transmission network consists of $345 \mathrm{kV}$ lines, supported by lines of various lower voltages, most of which are $115 \mathrm{kV}$. Compared to some other parts of the Eastern Interconnection, the ISO New England system is relatively isolated and self-sufficient. New England is bordered to the northeast by New Brunswick, with which it has only one link, a 345 $\mathrm{kV}$ line that has the physical capability to import up to $700 \mathrm{MW}$. To the north, New England is bordered by Quebec, but the two systems are connected only by means of two DC ties, one with a maximum physical capacity of $2000 \mathrm{MW}$, and the other with a maximum physical capacity of $225 \mathrm{MW}$. To the west and south, New England is bordered by New York, and the region's ties to the greater part of the Eastern Interconnection are through New York. 
New England Ties with New York. New England has seven ties with New York: three $115 \mathrm{kV}$ lines into Vermont, one $345 \mathrm{kV}$ line and one $230 \mathrm{kV}$ line into Massachusetts, one $345 \mathrm{kV}$ line into Connecticut, and one $138 \mathrm{kV}$ underwater cable between Long Island and Connecticut. Together, these lines can support the transfer of between 1300 and $1500 \mathrm{MW}$ into New England during the summer. It is important to note that the underwater cable has experienced significant operational difficulties in the past two years. The cable, operated by Long Island Lighting Company (LILCO) and Connecticut Light and Power Company (CL\&P), was rendered inoperable during a storm in December 1996. Prompt action by the utilities enabled the cable's return to service for the summer of 1997. More recent problems have required additional repair work to ensure the cable's availability for summer of 1998. Although the cable (when operable) does not increase the total import capability into New England appreciably, it is of particular value for providing voltage support in Connecticut. The availability of such voltage support could be critical to averting a voltage collapse if the Connecticut area were to experience an unplanned outage of one of its $345 \mathrm{kV}$ lines during a period of high demand. Permanent loss of the cable would increase the need for additional and appropriately located generating capacity within New England. (See box on "voltage collapse," next page).

New England Ties with Quebec. New England is connected to Quebec through two high voltage direct current (HVDC) links. One is located in northern Vermont (Highgate) and is normally limited to $200 \mathrm{MW}$; it can carry up to $225 \mathrm{MW}$ for short periods during an emergency. The other link is a 941-mile long HVDC line known as the Phase II facility, which runs from the Radisson substation near James Bay to the Sandy Pond substation in Ayre/Groton, Massachusetts. The Phase II link itself is physically capable of handling up to $2000 \mathrm{MW}$.

Capping the import capability of the Phase II link at $1200 \mathrm{MW}$ was necessary because of the physical configuration of the Eastern Interconnection. About 75 percent of the generation in the interconnection is located west of the Allegheny mountains. If a large generator in the eastern part of the interconnection (or the Phase II facility, which "behaves" as if it were a large generator sited at Ayre/Groton, where its DC energy is converted to $\mathrm{AC}$ and fed into the interconnection) were to shutdown abruptly, all other generators operating on the interconnection would automatically increase their output to keep the system in balance. This would result in an increase in generation in the west, and the electricity produced would flow to the loads in the east via the transmission lines that run west-to-east across New York and Pennsylvania. These lines are normally heavily loaded. A large unplanned increase in the power flow on the lines could overload some of them, causing them to shutdown automatically to avert physical damage. In turn, this could induce a voltage collapse and lead to a widespread outage. Accordingly, the operators of the New York and PJM systems continuously monitor and control the flow on critical lines so that the unplanned outage of any one of the largest generators in their respective areas (and neighboring areas) would not cause voltage stability problems. Similarly, ISO New England normally limits the flow on Phase II so that the impact of its loss, if it occurred, would be comparable to the loss of the output of the largest generation facility in New York and PJM, i.e., $1200 \mathrm{MW}$. 
Until recently, there were two major limitations on NEPOOL members' interest in Hydro Quebec as a supplier, despite the relatively low cost of the electricity that would be provided. One is the need, as discussed above, to cap the operative capacity of the Phase II facility at $1200 \mathrm{MW}$, to avoid creating an incremental reliability risk for others on the Eastern Interconnection. The second limitation was the potential for a complete blackout of the Quebec interconnection, a development which last occurred in March, 1989. The Phase II facility is not subject to this risk, because although its power source is owned and operated by Hydro Quebec, the power source is electrically isolated from the Hydro Quebec AC network. However, all other ties between the Eastern Interconnection and Hydro Quebec, unless they were to be served by similarly isolated generation sources, were collectively limited to imports totaling about $1200 \mathrm{MW}$ because of the risk that all Hydro-Quebec generation might be lost as a single contingency.

Hydro Quebec recently completed a program to improve the reliability of its transmission system through extensive capital investments and revisions of established procedures and methodologies. These efforts brought the Hydro Quebec system into full compliance with all NPCC reliability criteria on May 1, 1998. The practical result of this change is that the loss of the entire Hydro Quebec system is no longer considered a single contingency. This change will have little impact in the short-term because the loss of the Phase II facility was always considered the major factor in loss of the entire system. In the future, however, it may have a significant impact on the addition of new ties from Hydro Quebec because planners will be able to consider the loss of individual links, rather that the entire Hydro Quebec system, easing limitations on the total amount of power that can be imported.

In terms of the summer of 1998 , there are additional factors at work that have impacted the flow of power between Hydro Quebec and New England. Planners must still consider what would happen to the heavily loaded transmission lines that run east-west across New York and Pennsylvania if power was lost at Phase II (the largest first contingency). This summer, however, power flow has increased in the east-to-west direction as utilities in the Mid-West region purchase power to meet their severe demand needs. This shift in flow direction has freed up constraints on the east-west lines, allowing for more power to be imported over the Hydro Quebec ties. As a result, officials at ISO New England have been able to increase their imports from the Phase II facility to around $1800 \mathrm{MW}$. It is important to remember that this shift in 
power flow is a temporary condition and may change at any time in the future.

Negotiated arrangements with New York Power Pool, Quebec, PJM, and New Brunswick have been made to import as much as 800 additional MW from Hydro-Quebec and other sources under emergency conditions. In operational terms, one or more of ISO New England's members would pay the incremental costs for utilities in other areas to adopt an economically suboptimal pattern of generation, so as to "unload" the transmission lines needed for the additional imports into New England. The specific amount of additional capacity obtainable under these arrangements would vary depending on the availability of generation from pertinent sources outside New England, the amount of lead time provided to the suppliers (who in some cases would have to "warm up" generating units), and the loads on the transmission grid both inside and outside New England.

As a result of the uncertainty associated with these emergency agreements, the region's planners do not incorporate these potential additional imports into their normal supply/demand calculations. Rather, the potential additions remain as a safety factor that can be used only under emergency conditions, and they are over and above the estimated relief obtainable through the actions in OP-4. (See discussion below of Operating Procedure No. 4 -- Actions During a Capacity Deficiency, especially Action 6.)

\section{INTERPOOL COMMUNICATIONS}

Operating representatives from ISO New England participate with operating management personnel from the other NPCC areas in regularly scheduled conference calls to discuss operations expected during the coming 10-day period. If adverse weather or system operating conditions are expected, any area may request NPCC to arrange a conference call to discuss operating details with appropriate operations management personnel from the NPCC areas and neighboring systems. ISO New England would use this procedure to activate the previously negotiated arrangements to increase its import capability.

In a further effort to increase interpool communications during the summer of 1997, weekly telephone conferences were held to keep NERC, NPCC, DOE, and the region's state regulatory authorities apprised of current and projected system conditions.

\section{USE OF SPECIAL OPERATING PROCEDURES}

ISO New England is also responsible for implementing "special operating procedures" designed to maintain the system's reliability in the event of an actual capacity shortfall. ISO New England's operating criteria state that the power pool should, at all times, have sufficient generation available to meet system demand plus an operating reserve equal to the largest facility then in use on the system plus half the rated size of the next largest facility then in use. Anything less than this is defined as a capacity deficiency, and requires the initiation of Operating 
Procedure No. 4 -- Actions During a Capacity Deficiency (OP-4). ${ }^{1}$ The actions anticipated under OP-4, and their expected impacts upon system demand, are shown in Table 1 below. When needed, the measures are usually (though not necessarily) adopted in the sequence listed. Over the past two summers, ISO New England has gained substantial experience in effectively and efficiently implementing the OP-4 operating procedures.

If the measures in OP-4 were not sufficient to establish and maintain a balance between load and available supply, ISO New England would have no choice but to invoke its Operating Procedure No. 7 -- Action in an Emergency (OP-7). ${ }^{2}$ To date, neither ISO New England, nor its predecessor NEPOOL, have ever experienced a situation requiring the use of OP-7. The procedure involves two methods of involuntary load curtailment," "feeder rotation," also known as "rolling blackouts," and "load shedding."

Feeder rotation is the less severe of the two, and involves temporary disconnection of some of the utility's distribution circuits. After a specified period of time, if demand still exceeds available supply, a second group of circuits is deenergized for a similar period, and service is restored to the first group. This rotational technique is continued as long as circumstances require it. It minimizes the adverse impacts imposed on specific customers, and enables the continuation of service to essential facilities such as hospitals, fire departments, and police stations. However, the situation may require a more rapid or a larger reduction in load than is achievable through feeder rotation, requiring the utility to turn to load shedding. Load shedding involves cutting off service to all customers in broader geographic areas, perhaps with little or no notice, and the affected utility might not be able to keep power supplied to essential facilities in those areas. Whether an affected utility would use one technique or both, in what proportions and over which geographic areas, would depend on the circumstances, especially the location of any unexpectedly out-of-service generation or transmission facilities in relation to major loads.

\section{"ENERGY ADVISORY" SYSTEM}

ISO New England and the region's electric companies are keenly aware of the need to keep public officials, media, and the general public accurately informed about the status of the electric supply system, especially during the summer months when the likelihood of a capacity deficiency is greatest. To aid in achieving this objective, ISO New England has adopted the following fivecategory "Energy Advisory" system, modeled after the notification system used by the National Weather Service for weather advisories:

- "Normal" - no advisories in effect.

1 For the official text of OP-4, see Appendix A.

2 See Appendix B for official text of OP-7.

3 Such curtailments would be "involuntary" from the perspective of the customer; they would be voluntary from the perspective of the utility, to reduce the risk of costly and long-lasting damage to generation or transmission facilities. 
- "Conservation Day" - ISO New England issues a public appeal to customers to conserve electricity in anticipation of unhealthy air quality conditions and heavy electricity demand, usually during hot and humid weather.

- "Power Caution" - This is a notification that electric reserves are lower than normal and steps are being taken to maintain the integrity and reliability of the on-line generation and transmission facilities. No public action is needed.

- "Power Watch" - A public appeal is issued when electricity demand is high and there is a possible need to reduce system voltage or implement other measures to safeguard the system. Customers will be asked to consider turning off unnecessary appliances and lights. A "power watch" corresponds to step 9 of OP-4.

- "Power Warning - A more urgent public appeal is issued when an immediate reduction of electricity usage is needed to avert overload of the electric system. A "power warning" corresponds to step 15 of $\mathrm{OP}-4$.

Changes in the status of these advisories are announced to public officials and the media through the ISO New England and CONVEX Web Pages; automated fax, e-mail and telephone systems; and personal telephone calls to key individuals.

The use of the special operating procedures and the energy advisory system were an integral part of ISO New England's effort to address the capacity shortfall experienced during the summer of 1997. The advisory system was implemented 16 times during the 1997 summer. Specifically, there were 3 Conservation Day, 11 Power Caution, and 2 Power Watch advisories issued in June, July and August. OP-4 was implemented on five days during this period. On each of these days a Power Caution was issued.

\section{ACTIONS TAKEN DURING SUMMER 1997}

The New England region has struggled with electricity supply shortages for some time as a result of the shutdown of a substantial quantity of nuclear generating capacity. Over this period -- and especially during the summer of 1997 -- officials from ISO New England and the region's electric companies developed a great deal of knowledge and experience that has enabled them to effectively manage the electricity system, ensuring reliability despite the shortfalls. This experience will continue to be an important resource that officials will be able to draw upon in their efforts to address capacity concerns for the summer of 1998.

The following is a summary of the major actions taken by NEPOOL (as the predecessor to ISO New England) and the region's utilities to address capacity issues during the summer of 1997 :

- The energy advisory system outlined above was developed in April 1997. The system was the result of a review and revision of NEPOOL's existing Communications Guidelines that provide the notification scheme, contact points, and pre-formatted examples of information notices to be used for communicating abnormal or emergency operating conditions.

- The seven-week refueling of the Seabrook nuclear unit was rescheduled from June 28, 1997 
to May 10,1997, ensuring that the $1,162 \mathrm{MW}$ plant would be available to meet electricity demand during the summer peak period. The majority of the approximately $\$ 3$ million cost for rescheduling the refueling was funded by NEPOOL.

- In January 1997, a Capacity Situation Task Force (CSTF) was established, comprised of NEPOOL and its member utilities as well as representatives from every state within New England. The mission of the task force was to review the 1997 summer capacity situation, quantify the amount of resources (load relief and/or capacity additions) needed to ensure that the summer period reliability level would be at least equal to the planning criterion and to recommend a list of options for mitigating the projected summer capacity situation. In February 1997, the CSTF created the Interruptible Loads Task Force which was responsible for developing an estimate of the potential dispatchable loads available within the industrial and commercial sectors and recommending proper compensation for these loads.

- NEPOOL implemented a special interruptible load program for the period between May 15 and September 15, 1997. This program established a special compensation rate of $\$ 8$ per $\mathrm{kW}$ of daily average load relief for the period between June and September. Costs of the program were allocated pro-rata to NEPOOL members based on the actual average of their July and August 1997 monthly capability responsibility. As a result of this program, contracts for approximately $540 \mathrm{MW}$ of interruptible loads were established by NEPOOL members with their customers. The projected potential for the program was $440 \mathrm{MW}$.

- NEPOOL members also instituted a 1997 summer generating resource program through which NEPOOL paid for the costs associated with bringing an additional $500 \mathrm{MW}$ of generating capacity online. The additional generating capability included the reactivation of both utility and non-utility owned generating units, the physical upgrading of existing generators to provide maximum output during emergency conditions, the installation of chilling equipment on several gas turbine units to boost output during hot weather, the purchase of capacity from exempt wholesale generators, and the temporary leasing of mobile generators. NEPOOL members agreed to share the costs of the program based on a pro-rata share of their respective average July and August 1997 monthly capability responsibility. ${ }^{4}$

- NEPOOL and member utilities installed shunt capacitors on key parts of the $115 \mathrm{kV}$ portion of the Connecticut transmission grid. These devices enabled usage of the transmission system for electricity imports into Connecticut at a higher level ( $+420 \mathrm{MW}$ overall). Reinforcement of the transmission system in parts of western Massachusetts and eastern New York was instituted so that if Connecticut is under stress, certain areas of Connecticut can be supplied by Massachusetts and New York utilities.

- NEPOOL member utilities took a number of additional measures prior to and during the 1997 summer including rescheduling of all possible generator and transmission maintenance away from the summer peak period; stepping up of preventive maintenance of generating units and transmission facilities; coordination with neighboring power systems to augment NEPOOL's ability to purchase and import emergency power; review and testing of operating practices and procedures and training of system operators to handle abnormal system conditions;

4 See Appendix $\mathrm{C}$ for detailed list of generation additions. 
thermal scanning of all critical transmission circuits for hot spots in need of repair; testing, maintenance and/or installation of bulk transmission and distribution level capacitors; and ensuring that adequate tree clearance is maintained in all transmission right-of-ways. 
Table 1. Summary of OP-4

Energy

Advisory Action

Status Number Description of Action

Est. Impact --

\begin{tabular}{|c|c|c|c|}
\hline $\begin{array}{l}\text { "Power } \\
\text { Caution" }\end{array}$ & 1,2 & Call for maximum output from generators & 160 \\
\hline $\begin{array}{l}\text { "Power } \\
\text { Caution" }\end{array}$ & $3,4,5$ & Reduce service to customers on interruptible contracts & 20 \\
\hline $\begin{array}{l}\text { "Power } \\
\text { Caution" }\end{array}$ & 6 & Purchase emergency power from other systems & $500-1,000$ \\
\hline $\begin{array}{l}\text { "Power } \\
\text { Caution" }\end{array}$ & 7,8 & Call on additional interruptible contracts & $220^{2}$ \\
\hline $\begin{array}{l}\text { "Power } \\
\text { Watch" }\end{array}$ & 9,10 & $\begin{array}{l}\text { Cut intra-utility usage, call on additional interruptible } \\
\text { contracts }\end{array}$ & $140^{2}$ \\
\hline $\begin{array}{l}\text { "Power } \\
\text { Watch" }\end{array}$ & 11 & Allow a portion of operating reserve to serve load & 575 \\
\hline $\begin{array}{l}\text { "Power } \\
\text { Watch" }\end{array}$ & 12,13 & $\begin{array}{l}\text { Implement } 5 \% \text { voltage reduction } \\
\text { Commit a major portion of operating reserve to load }\end{array}$ & $\begin{array}{r}450^{2} \\
1000\end{array}$ \\
\hline \multirow[t]{2}{*}{$\begin{array}{l}\text { "Power } \\
\text { Warning" }\end{array}$} & 14,15 & Radio, TV appeals for voluntary load curtailment & 435 \\
\hline & & Maximum relief available through $\mathrm{OP}-4$ & $3,500--4,000$ \\
\hline
\end{tabular}

\section{Notes to Table 1}

1. Data source: OP-4 Appendix I (revised 6-30-98). See Appendix A of this report for details.

2. Estimate assumes peak load of $22,100 \mathrm{MW}$. 


\section{THE ELECTRICITY SUPPLY OUTLOOK FOR NEW ENGLAND AND CONNECTICUT, SUMMER 1998}

\section{NEW ENGLAND OUTLOOK}

The regional electricity supply outlook for the summer of 1998 is summarized in Table 2 below. The table shows that barring some combination of unusual circumstances, the region's electricity supplies are likely to be sufficient to avoid serious disruptions, though certainly not ample. Recent developments described below, including the restart of Millstone unit 3, have significantly increased the likelihood that the region will be able to meet summer demand with little impact on customers. However, it is important to recognize that if the regional supply system experiences a high level of unplanned generation or transmission outages at the time demand peaks in a normally hot summer, the system might need to invoke some of the demandreducing measures in Operating Procedure \#4 in order to maintain a balance between supply and demand. Furthermore, it is possible that if the system experiences particularly adverse conditions, such as additional unplanned outages, perhaps in combination with abnormally hot weather, ISO New England could be forced to invoke Operating Procedure \#7, under which load is reduced to the extent required through feeder rotation and load shedding.

It is important to note that there are a number of factors that are beyond the control of ISO New England and New England electric companies that could affect their ability to meet demand. The principal concerns highlighted by ISO New England officials include:

- Extreme weather conditions that could raise peak demand higher than the expected level.

- Loss of generation or transmission beyond planned contingency levels.

- Reduction of imports into New England or Connecticut to below planned levels, due to unplanned outages of generating capacity or the outage of critical transmission facilities.

- Customer behavior.

\section{CONNECTICUT OUTLOOK}

The electricity supply outlook for the Connecticut portion of ISO New England is shown in Table 3 below. The table shows that as long as Connecticut's unplanned generation outages do not exceed the typical $750 \mathrm{MW}$ and electricity imports are available at the maximum level (2000MW) Connecticut will be able to meet a record system peak of $6200 \mathrm{MW}$, with a small margin to spare. As with the New England region as a whole, the restart of Millstone unit 3 and other recent developments will provide important additional resources for meeting demand in Connecticut during the summer of 1998. 


\section{Table 2. New England Electricity Supply Assessment, Summer 1998 (MW)}

a. Installed generation capability in New England (1998)

$22,990^{1}$

b. Net firm purchases from Hydro-Quebec, New York, New Brunswick

$2,050^{2}$

c. Hydro-Quebec Firm Energy Contract

d. Additions to generation (1998)

d. Total NEPOOL resources

e. Generation out of service (Millstone 2, Bridgeport Harbor 3)

f. Allowance for unplanned outages

g. Projected resources available at peak load

h. Operating reserve

I. Expected 1998 peak load (normal summer weather)

j. Total NEPOOL requirement

k. Potential shortfall at peak (w/o relief actions)

1. Additional load placed under interruptible contract (1998)

m. Adjusted shortfall potential

n. Relief through OP-4 measures (estimated range)

\section{Notes to Table 2}

1. Includes Millstone units 2 and 3. Does not include Millstone unit 1.

2. Up to $1000 \mathrm{MW}$ of additional purchases could be available under OP-4, Action 6 .

3. The Bridgeport Energy plant is scheduled to be available in early August. This will result in an additional $230 \mathrm{MW}$ of generating capacity.

4. NEPOOL's rules require it to maintain an operating reserve, even when under some stress, equal in MW to loss of the region's largest supply source (i.e., the Phase II DC link to Hydro-Quebec, rated at $1,500 \mathrm{MW}$ ) plus half its second-largest source (the nuclear unit, rated at 1,160 MW). Without a sufficient reserve to cover such contingencies, the region would represent a significant risk to others on the Eastern Interconnection, and it would not be operating in accordance with its formal obligations to them. Note that OP-4 calls for committing about a third of the reserve in step \#11, and most of the remainder in step \#13.

5. See Table 1, p. 11 for details on projected relief through OP-4 actions. 
Over the past few years, ISO New England and CONVEX analysts, recognizing that Connecticut is the most vulnerable area in the ISO New England region, have developed an analytic procedure to aid them in containing and managing periods of insufficient capacity with the least possible inconvenience and disruption to consumers. The procedure is based on an hourly forecasting and analysis system for Connecticut that continually updates the area's plans to optimize the use of its generating equipment and load relief actions in the event of major unplanned generation or transmission outages.

\section{MAJOR CONCERNS FOR THE 1998 SUMMER}

The major change affecting the New England summer 1998 capacity situation is an expected increase in consumer demand. In 1997, ISO New England recorded an actual peak demand of $20,569 \mathrm{MW}$ on July 14. This load was $50 \mathrm{MW}$ higher than the previous all-time peak load experienced in 1994. For 1998, however, officials are forecasting that peak demand will increase to $22,100 \mathrm{MW}$. This expected increase is largely attributable to continued economic growth in the region. In addition, the summer of 1997 was one of the coolest experienced by New England in recent history, with most of the hot and humid weather occurring during the week of July 13.

Data from the 1998 summer to date appears to support projections of increased consumer demand. On July 22, ISO New England recorded a peak demand of 21,361 MW -- a new record peak. Demand on this date was also acute in Connecticut where the peak reached 5,799 MW -only $400 \mathrm{MW}$ shy of the state's projected 1998 peak demand of $6,200 \mathrm{MW}$. In addition, weather forecasts for the remainder of the summer of 1998 indicate that conditions on average will continue to be slightly warmer than last year. ${ }^{5}$

Despite this projected increase in demand for the summer of 1998, a review of Table 2 indicates that the amount of generating capacity in the New England region has remained relatively constant since last year. Officials from ISO New England, however, maintain that the region will continue to have sufficient resources to meet their planning criteria. In fact, their projected use of OP-4 procedures on eight to ten days during the 1998 summer peak period is similar to their projections for 1997 . The ability to meet increased demand will primarily result from an increased reliance on imported power. In order to meet their capacity requirements, ISO New England utilities have entered into an unprecedented number of firm contracts over the New York transmission lines. As a result, more power will be coming into the region as a function of normal operational procedures relative to last year.

${ }^{5}$ See Appendix D for a profile of New England and Connecticut's electricity load for the first half of the 1998 summer. 


\section{Table 3. Connecticut Electricity Supply Assessment, Summer 1998 (MW)}

\section{SUPPLY}

a. Total installed generation (as of 7/98) $5,950^{1}$

b. Generation out of service (Millstone 2, Bridgeport Harbor 3) 1,250

c. Remaining generation (line a minus line b) 4,745

d. Generation added (since 9/97) $0^{2}$

e. Transmission import capability (1998) 2,000

f. Additional transmission import capability (1998) 0

g. Maximum resources available for peak load (Sum of lines $c, d, e, f$ )

\section{LOAD}

h. Expected peak load $\quad 6,200$

I. Less: Load transferrable to Mass. \& New York utilities 365

j. Less: Load reduction obtainable under existing OP-4 250

k. Less: Load reduction through additional (1998) interruptible 75 contracts

1. Net peak load (line $h$ minus (sum of lines $I, j, k$ ))

\section{RESERVES}

m. Reserve available (for unplanned outages or unanticipated demand) (line $g \quad 1,235$ minus line l)

n. Typical unplanned outages $\quad 750$

o. Remaining reserve (line m minus line $n$ ) 485

\section{Notes to Table 3}

1. Includes Millstone units 2 and 3. Does not include Millstone unit 1.

2. The Bridgeport Energy plant is scheduled to be available in early August. This will result in an additional 230 MW of generating capacity. 


\section{DEVELOPMENTS IN GENERATING AND TRANSMISSION CAPACITY}

The current electricity supply situation in New England is in a period of rapid change. New developments are occurring in the area of generation capacity that will significantly affect the region's ability to meet demand during the summer of 1998 and beyond.

The major impetus for the current supply shortage was the shutdown of a substantial quantity of nuclear generating capacity in the region. The loss was specifically compelling for the state of Connecticut, where the shut-down of three Millstone units in spring 1996, due to non-compliance with safety standards, resulted in the unavailability of $2,630 \mathrm{MW}$ of capacity. Since the shutdown of Millstone, Northeast Utilities, the plant's primary owner, has put a great deal of resources into improving conditions and gaining approval from the Nuclear Regulatory Commission (NRC) for a return to service. To date, the utility has spent more that $\$ 1$ billion on its efforts to restart the plant and the purchase of replacement power and capacity.

\section{Restart of Millstone 3}

On June 29,1998 , following an extensive regulatory review process, final approval was granted by the NRC to restart Millstone unit 3, the largest of the three units, representing $1,150 \mathrm{MW}$ of capacity. Following a short start-up period, Millstone unit 3 began operating at 100 percent capacity on July 14,1998 . To date, the unit continues to operate at full capacity with no major incidents. Citing the difficulties in bringing a major nuclear plant back into operation after two years of inactivity, Northeast Utilities officials remain cautiously optimistic that the unit will continue to be available to meet demand needs for the remaining portion of the 1998 summer peak period.

The additional capacity provided by the restart of Millstone unit 3 will significantly enhance the ability to meet demand in Connecticut and New England. The decision to restart Millstone unit 3 was widely anticipated, although official planning estimates for the summer peak season were calculated to ensure sufficient capacity regardless of the unit's status.

With Millstone unit 3 back in operation, Northeast Utilities is focusing its attention on Millstone unit 2. Officials hope to gain NRC approval for restart of Millstone unit 2 by the end of the year. The unit, rated at $870 \mathrm{MW}$, must overcome similar hurdles to those of Millstone unit 3 and demonstrate that all technology specifications, procedures, and training programs meet NRC requirements. Based on the results of an economic feasibility study, Northeast Utilities has decided to retire Millstone unit $1(660 \mathrm{MW})$. The unit faced complicated problems that would have made restart especially challenging. In particular, the unit was designed as a turn-key facility in the 1960's and, as a result, it does not have site-specific technology specifications. Without this information, it would have been more difficult for the utility to demonstrate that the facility had been corrected to meet NRC's stringent requirements. 


\section{Closure of Bridgeport Harbor Unit 3}

On May 22, 1998, additional generating capacity in the state of Connecticut was lost when an operating error led to sea water intake in a boiler at the Bridgeport Harbor power plant. The accident resulted in the immediate shutdown of Bridgeport Harbor unit 3, rated at $375 \mathrm{MW}$. The plant's owner, United Illuminating, hopes to have the unit back into operation by the end of July.

\section{Temporary Outage at Seabrook}

Located in New Hampshire, Seabrook nuclear power plant, is jointly owned by eleven New England utilities and operated by North Atlantic Energy Service Corporation, a subsidiary of Northeast Utilities. On June 11 , the $1,160 \mathrm{MW}$ plant was forced to shutdown after an air conditioning and ventilation unit failed, rendering the facility's primary and backup systems inoperable. Repairs were made at the plant enabling it to return to service starting on July 10 . The plant is once again running at full capacity. Loss of the Seabrook plant was a particular hardship during a period of high demand experienced in late June, compounding the impact of the Millstone unit 3 and Bridgeport Harbor unit 3 outages. According to officials at Northeast Utilities, Seabrook will continue to operate until the next refueling which has been scheduled for May 1, 1999. At that time, the utility will replace the air conditioning system with a newlydesigned, state-of-the-art system that has been approved by the NRC.

\section{New Capacity Planned at Bridgeport Energy Facility}

Bridgeport Energy LLC, a group comprised of affiliates of United Illuminating and Duke Energy Power Systems is currently building a $\$ 260$ million, $520 \mathrm{MW}$ gas-fired combustion turbine at United Illuminating's Bridgeport Harbor power plant. When completed, the plant will be Connecticut's largest non-nuclear generating plant. The facility has been designed with advanced technology that will make it one of the cleanest burning fossil fuel-fired generating plants in the nation, while maintaining highly efficient operation. The plant is scheduled to begin operation in two phases. Installation of the phase one portion, two simple-cycle turbines rated at $340 \mathrm{MW}$, has been completed. Bridgeport Energy has begun testing the system and hopes to have both units providing power to the region by August 15. Start up of this facility will require the shutdown of Bridgeport Harbor unit 1, an $80 \mathrm{MW}$ oil-fired unit, so that the new plant can be connected at the Pequonnock substation. Bridgeport Harbor unit 1 will be in cold reserve mode and United Illuminating will be able to reactivate it to maintain system reliability if the Bridgeport Energy plant is not functioning. By the summer of 1999, phase two of the Bridgeport Energy facility, two heat recovery steam generators and a steam turbine, will increase the facility's capacity to $520 \mathrm{MW}$. 


\section{SUMMARY OF RECENT ACTIONS TAKEN BY NEPOOL AND CONNECTICUT UTILITIES TO PREPARE FOR THE SUMMER OF 1998}

ISO New England Actions: As we have seen, ISO New England and the region's utilities have been working for the past two years to augment electricity supplies and prepare to meet demand and maintain the integrity of the electric supply system. The following list of actions taken to prepare for the summer of 1998 represent a continuation and extension of these efforts:

- Increased preventive maintenance for generation and transmission facilities to help maximize their availability. In the event of unscheduled maintenance problems, generation continues to be dispatched to maximize unit availability.

- Negotiated arrangements with New York Power Pool, Quebec, PJM, and New Brunswick to augment NEPOOL's ability to import power from Hydro-Quebec or others under emergency conditions. The specific amount of additional capacity obtainable under these arrangements will vary depending on the availability of generation from external sources, the amount of lead time provided to the suppliers, and the loads on the transmission grid both inside and outside New England.

- Maintained communications with neighboring power systems to maximize the ability to import additional electricity when necessary. For example, ISO New England has worked with Hydro Quebec to ensure that repairs to the Highgate link, necessary as a result of the severe ice storms that occurred during the winter of 1997, will not be conducted during periods of peak summer demand. This agreement will ensure that there will be no impact on the ability to import electricity during peak periods.

- Rescheduled plant maintenance for key facilities to ensure their availability during the summer of 1998.

- ISO New England conducted system-wide voltage reduction and load shedding simulation tests. In addition, utilities have reviewed and revised as necessary, utility-specific load shedding procedures.

- Educated electricity customers about conservation tips and the energy advisory system. Steps taken include posting information on ISO New England, CONVEX and utility web sites; providing updates on the region's capacity situation to the press and local government officials; developing bill inserts and customer literature; and conducting meetings between utility representatives and key emergency management personnel.

- Continued to solicit customer participation in interruptible contracts with utilities.

- Implemented a "conservation customer" program in coordination with New England's environmental protection agencies. The program calls for utilities to sign up commercial customers who agree that when a Conservation Day warning is implemented they will take steps to reduce their energy use and will remind all employees to implement conservation measures at home and at the office. Northeast Utilities, for example, has signed up 245 conservation customers in Connecticut, New Hampshire, and Massachusetts. 
Connecticut Actions. Many of the actions mentioned above have been implemented across the New England region and thus apply also to Connecticut. A variety of special actions have been taken by CONVEX and Connecticut utilities, primarily in preparation for the summer of 1997, to address the state's specific capacity concerns. These actions, such as installation of shunt capacitors on key parts of the Connecticut transmission grid, reinforcement of the transmission system to allow for additional imports, and development of an hourly forecasting system for management of Connecticut generation commitment and load relief will continue to support the reliability of the state's electric system in the summer of 1998.

\section{CONCLUSIONS AND RECOMMENDATIONS FOR THE SUMMER OF 1998}

\section{Conclusions}

1. ISO New England and its member entities have made systematic efforts to deal with the region's electricity supply problems for this summer. No indications have been found that significant additional measures of a practical and short-term nature were not considered or investigated. Experience gained over the past two years has enabled ISO New England officials to develop a state-of-the-art, well-organized response mechanism that enables them to take all available measures to meet demand requirements while minimizing impacts upon customers.

2. The major factor impacting the New England summer 1998 capacity situation is an expected increase in consumer demand, largely attributable to continued economic growth in the region. In order to meed this increased demand, New England utilities have entered into an unprecedented number of firm energy contracts for imports over the New York transmission lines. As a result, the region will be more reliant on imported power to meet day-to-day needs.

3. The organizational change from NEPOOL to ISO New England has had no apparent impact on the reliability of the region's electricity infrastructure. The officials at ISO New England show every indication that they will continue NEPOOL's strong commitment to ensuring reliability.

4. Barring some combination of unusual circumstances, the region's electricity supplies are likely to be sufficient to avoid serious disruptions, though certainly not ample. Recent developments -- especially the restart of Millstone unit 3 -- have significantly increased the likelihood that the region will be able to meet summer demand with little impact on customers. However, it is important to recognize that if the regional supply system experiences a high level of unplanned generation or transmission outages at the time demand peaks in a normally hot summer, the system might need to invoke some of the demandreducing measures in Operating Procedure \#4 in order to maintain a balance between supply and demand. Furthermore, it is possible that if the system experiences particularly adverse conditions, such as an abnormally high rate of unplanned outages in combination with abnormally hot weather, ISO New England could be forced to invoke Operating Procedure 
\#7, under which load is reduced to the extent required through feeder rotation and load shedding.

5. Despite the utilities' preparations, combinations of adverse conditions may occur. If so, the actions planned under OP-4 and OP-7 should be understood by those affected not as privations but rather as an important safety net. Their use, when conditions warrant, is essential to protect the region from a broader and much more long-lasting outage that could result if the regional electric system were allowed to "crash" as opposed to being brought to a "controlled landing."

6. Successful implementation of OP-4 and OP-7, if needed, will depend on thorough preparation by ISO New England and its member entities, including the development and testing of mechanisms for informing and coordinating with government agencies, the media, and the general public. ISO New England and CONVEX have made major strides in this area over the last two years and, as a result, a well-organized communication network is now in place for the 1998 summer peak period.

7. ISO New England and its predecessor NEPOOL have never had to employ OP-7, and over the past decade the conditions requiring the use of OP-4 have arisen unevenly across the region. This means that people in some areas are probably more familiar with the procedures than others. In these circumstances, it is important for ISO New England and its members to continue to institute suitable tests and drills related to these procedures, to review methodically any actual applications of the procedures for "lessons learned," and finally, to take actions as appropriate to follow through on lessons learned.

\section{Recommendations}

1. ISO New England and its members should continue to take steps to ensure their readiness to implement OP-4 and OP-7 if needed. These actions should include appropriate tests or drills and review of any actual application of the procedures for lessons learned.

2. ISO New England should take steps to share their experiences in dealing with capacity shortages with other regional power systems within NPCC and with the industry at large through NERC.

3. ISO New England and its members should continue to maintain their communication network and support customer outreach and education about the energy advisory system and the potential need to implement operating procedures.

4. ISO New England should continue to closely monitor the emerging developments in the region's generating capacity. In particular, they should confirm that Millstone 3 and Seabrook continue to have a smooth transition back into service, that actions continue to support the restart of Bridgeport Harbor and Millstone 2, and that progress continues towards the completion of Phase One of the Bridgeport Energy project. 


\section{ELECTRICITY SUPPLY OUTLOOK FOR NEW ENGLAND FOR THE SUMMER OF 1999 AND BEYOND}

ISO New England and the region's utilities have taken numerous steps over the past two years to address the electricity supply shortage that resulted from the unavailability of a substantial quantity of nuclear generating capacity in the region. Given that multi-year lead-times are required for many of the possible options for upgrading a region's electricity supply system, it is clear that utilities and public officials must also prepare for the summer of 1999 and beyond.

The long-term outlook for New England's electricity supply is heavily influenced by the impending transition to a competitive marketplace for electricity. Within the next few years, many of the traditional utilities will be required to divest themselves of all of their generating capacity, as a wide array of new energy providers begin to compete to supply wholesale power in a real-time marketplace. As a result, the market forces of supply and demand will begin to play an increasing role in determining the future of generating and transmission capacity in the region.

\section{TRANSMISSION CAPACITY}

In order to ensure the long-term reliability of New England's electricity infrastructure, it is imperative that the region have an adequate transmission system that ensures that power will move unconstrained both within New England and between New England and its neighboring power systems.

One of the most serious consequences of the shutdown of a large portion of the region's nuclear capacity, much of it in the Connecticut area, was the creation of a physical mismatch between the existing transmission system and the geographic distribution of the remaining generating capacity. In order to address this mismatch, Connecticut utilities made significant transmission investments, so as to increase the ability to import electricity into Connecticut; enable some customer loads to be shifted temporarily to New York and Massachusetts utilities if necessary; and reduce the risk of voltage instability or voltage collapse, given the new configuration of the bulk electric system. These actions were in response to relatively local problems resulting from the protracted outage of the nuclear units and were not necessary in other areas of New England.

Currently, New England's transmission system allows for an unconstrained transmission flow throughout the region and appears to be able to handle even exceptionally heavy load demands characteristic of the summer peak demand periods. On July 14, 1997, when ISO New England experienced a record peak load, thermal and stability transmission interfaces within the ISO New England control area were generally not constrained. The Connecticut import interface was only approximately 85 percent loaded during the summer's peak load periods.

Questions have also been raised concerning whether or not it would be advantageous for ISO New England to invest in transmission upgrades to allow for greater imports into its service territory. As with the Connecticut connections, the existing ties between ISO New England and 
its neighboring power systems seem to be sufficient to meet current needs. During the summer of 1997, ISO New England did not encounter any transmission overloading problems, although inter-pool tie lines were heavily loaded with import purchases. Furthermore, any improvements to the import ties are not likely to be cost-effective for ISO New England. Some very extensive renovations would be needed outside ISO New England's service territory, and ISO New England would receive only a part of the benefits. Other alternatives would almost certainly be more attractive, especially alternatives that would attack the underlying generation capacity shortage more directly.

Although it does not appear to make sense for the owners of New England's transmission system to invest in further upgrades, new lines may nevertheless result from competitive market forces. Currently, several proposals have been submitted to ISO New England requesting permission to build new lines that would be used at least part of the time to increase electricity imports into the region. These proposals include a 600 to $800 \mathrm{MW}$ line from Hydro Quebec and a transmission upgrade in Vermont. Utilities in these areas have expressed an interest in expanding into the emerging electricity marketplace in New England and throughout the United States.

\section{GENERATION CAPACITY}

In the next few years, substantial changes are likely to occur with respect to New England's internal generating capacity. As we have seen, the region's capacity has already increased significantly with the reopening of Millstone unit 3 . Additional restarts at Millstone 2 and Bridgeport Harbor and the opening of the new state-of-the-art Bridgeport Energy gas-fired power plant -- all of which anticipated this year -- will further augment New England's available resources. This added capacity will give officials more flexibility in managing the transition to a competitive electricity marketplace -- without having to simultaneously manage a worsening near-term electricity supply shortage.

Looking ahead to the next few years, it appears that competitive market forces are likely to bring about additional increases in New England's available generation capacity. New England states are expected to continue to move aggressively forward with their efforts to develop and implement legislation restructuring the electric utility industry. This legislation will have a major impact on generation of electricity in the region. For instance, Connecticut utilities must submit a plan by October 1,1998, outlining their plan for divesting their non-nuclear generating assets by January 2000 and their nuclear assets by January 2004 . Once divestiture is complete, electricity will be supplied by independent companies selling power through the wholesale marketplace. These companies will make decisions about developing further resources based largely on the laws of supply and demand.

Indeed, anticipation of the competitive electricity marketplace and the forces of supply and demand already appear to be having a major impact on the outlook for generation capacity in New England. According to a recent report by the PIRA Energy Group, the Northeast -particularly Massachusetts and Maine -- is projected to exhibit an exceptional growth in its generation capacity. Currently, there are over $28,000 \mathrm{MW}$ of new generation capacity under 
consideration for connection to the New England transmission grid. ${ }^{6}$ ISO New England will review these proposals to determine whether the existing transmission infrastructure will support the new generation. To date, ISO New England has approved transmission connections for more than 2,400 MW. A number of these plants, including the Bridgeport Energy facility, are already under construction. The remaining proposals are still in the early planning stages and it is unclear exactly how many of them will be built.

The amount of new generation being proposed for New England is especially remarkable considering that the 1997 peak load was 20,564 MW and that current installed capacity is 24,000 MW. According to one report, "even with substantial retirements of existing units not yet scheduled to come off-line, reserve margins would balloon to inconceivable levels." of the new facilities will be gas-fired power plants. Additions to the gas infrastructure could be needed to support the addition of such large amounts of new generating capacity.

In summary, the longer-term outlook for reliable, ample, and economically-priced electricity supplies in New England appears good. Officials at ISO New England and the region's electric companies have developed an effective and well organized response mechanism to respond to supply shortages, should they arise. In addition, market forces appear to be driving a dramatic move by energy suppliers to capitalize on the recent shortages by installing a large amount of new generation capacity that will ensure the region's ability to meet its demand needs for the foreseeable future.

${ }^{6}$ See Appendix E for a list of proposed projects being considered by ISO New England. This list has been prepared from information provided on ISO New England's website (www.iso-ne.com).

${ }^{7}$ Growing Prospects for Regional Electricity Imbalances, North American Electric Capacity Outlook, (PIRA Energy Group, April 1998). 


\section{APPENDIX A:}

\section{ISO New England}

\section{Operating Procedure No. 4}

Action During a Capacity Deficiency 


\section{ACTION DURING A CAPACITY DEFICIENCY}

APPROVED: October 9, 1969 by the NEPOOL Interim Operations Committee to be effective April 1, 1970

REVISED: $\quad$ BY the NEPOOL Operations Committee:

April 22, 1971

July 21, 1972

March 20, 1975

January 27, 1977

May 26,1977

May 25, 1978

September 14,1970

June 1, 1985

March 23, 1989, to be effective June 1, 1989

October 26, 1989

January 27,1994

September 13, 1996, effective with SPORT project May 30,1997

August 28, 1997, This revision incorporates the $9 / 13 / 97$ and the $5 / 30 / 97$ versions and is effective with the implementation of SPORT

REFERENCES: NERC POlicy No. 5, Emergency Operations

NPCC Emergency Operation Criteria $\mathrm{A}-3$

NPCC Operating Reserve Criteria A-6

NEPEX Operating Procedure No. 7 - Action in an Emergency (OP 7)

NEPEX Operating Procedure No. 8 - Operating Reserve (OP 8)

NEPEX Operating Procedure No. 10 - Power System Emergency Reporting Procedures (OP 10)

Criteria Rules and standards No. 16 NEPOOL Dispatchable Loads (CRS 16)

Master/Satellite Procedure No. 2 - Abnormal Conditions Alert (M/S 2)

Master/Satellite Procedure No. 3 -Curtailment of NEPOOI Dispatchable Loads (M/S 3)

SATELIITE INSTRUCTIONS:

CONVEX:

MAINE :

NEW HAMPSHIRE:

REMVEC:
Operating Instruction 0004 - Action During A Capacity Deficiency

Operating Procedure No. 4 - Action During A Capacity Deficiency

operating Procedure No. 4 - Action During A Capacity Deficiency

operating Procedure No. 4 - Action During A Capacity Deficiency 
This procedure establishes criteria and guides for actions during capacity deficiencies, as directed by Iso New England and as implemented by ISO New England and the Satellite Control Centers. This procedure may be implemented any time one or more of the following events, or other similar events, occur or are expected to occur:

- NEPOOL's available capacity resources are insufficient to meet the anticipated load plus operating Reserve requirements.

- One or more contingencies have occurred resulting in an immediate deficiency in NEPOOL's available capacity resources required to meet the load plus operating Reserve requirements.

- Transmission facilities into a subarea of NEPOOL are loaded beyond established transfer capabilities.

- A subarea of NEPOOL is experiencing abnormal voltage and/or reactive conditions.

- The need to implement manual load shedding as required by NEPEX Operating Procedure No. 7 - Action In An Emergency - is imminent but load shedding may be avoided, or reduced in magnitude, by application of this procedure.

- Another NPCC Area, or a remote system or pool, is experiencing a capacity deficiency and has requested assistance from Iso $\mathrm{New}$ England, which, if provided, will reduce NEPOOL's actual operating Reserve below the required levels.

Appendix I contains an estimate of the additional generation and load relief which will be achieved through implementation of the Actions specified in this procedure.

\section{PROCEDURE}

A. IMPLEMENTATION BY ISO NEW England

ISo New England will alert the satellites promptly any time one or more of the above conditions are anticipated, or have actually been experienced, and application of this procedure may be required. The alert will be issued in accordance with $\mathrm{M} / \mathrm{S} 2$. Upon implementation, Iso New England will notify the satellites of the Actions required by number. ISO New England and the satellites will initiate actions according to the authority and responsibility assigned by this document.

Action 1 through Action 10 will be implemented to the extent required to maintain full operating Reserve, in accordance with OP 8 and/or to provide necessary dispatch options during abnormal conditions. 
These first ten Actions of op 4 are considered routine in nature and do not result in degraded operating reliability since full operating resarve requirenents are naintained. These actions do not impact uBPOOr Participants' cuatonars beyond what is contractualiy provided. The quality of cuatomer service is not impacted by implenentation of lationa 1 through 10 of or 4 .

\section{ACTION 1}

(Note 1)

Order all on-line steam generation (including combined cycle) to Maximum Claimed Capability (MCC).

\section{ACTION 2}

Order all on-line internal combustion units to Maximum claimed Capability (MCC).

\section{ACTION 3}

(Note 2)

Curtail Type 2 NEPOOL Dispatchable Loads, Block E.

$$
\text { ACTION } 4
$$

(Note 2)

Curtail Type 2 NEPOOL Dispatchable Loads, Block D.

$$
\text { ACTION } 5
$$

(Note 2)

Curtail Type 2 NEPOOL Dispatchable Loads, Block c.

$$
\text { ACTION } 6
$$

Arrange to purchase available emergency capacity and/or energy from neighboring pools and companies.

\section{ACTION 7}

(Note 2)

Curtail Type 2 NEPOOL Dispatchable Loads, Block B.

\section{ACTION 8}

(Note 2)

Curtail Type 2 NEPOOL Dispatchable Loads, Block A.

Notes: 1. A NEPEX and Maine Satellite responsibility

2. A Satellite responsibility

3. A NEPEX responsibility

4. NEPEX and Maine responsible for plants, Satellites for office complexes. 


\section{4 \\ ACTION 9}

(Note 4)

Request voluntary load curtailment of NEPOOL Participants' facilities.

\section{ACTION 10}

(Note 2)

Request all of the customer generation contractually available to NEPOOL Participants.

Curtail Type 5 and Type 5-A NEPOOL Dispatchable Loads.

Actions 11 through 15 represent more extreme dispatch actions. Implementation of these actions may result in degraded system reliability since full operating reserve required for normal operation is not maintained. The quality of custoner service may be impacted by implementation of some of these Actions.

\section{ACTION 11}

(Note 3)

Allow the 30-minute reserve to go to zero.

Action 12 will be implemented to the extent required to maintain 10-minute reserve, in accordance with $O P$, and to enable Iso New England to better cope with continuing and deteriorating abnormal operating conditions.

\section{ACTION 12}

(Note 2)

Implement a voltage reduction of five percent of normal operating voltage requiring more than 10 minutes to implement.

(Note 3)

Alert the New York Power Pool (NYPP) that sharing of reserves within Northeast Power Coordinating Council (NPCC) may be required.

Action 13 normally will be implemented to maintain adequate 10-minute synchronized reserve in New England. The amount of 10-minute synchronized reserve to be maintained will be determined based on actual system conditions at the time of the shortage or the need to aid another NPCC Area under the NPCC Operating Reserve Policy.

Notes: 1. A NEPEX and Maine Satellite responsibility

2. A Satellite responsibility

3. A NEPEX responsibility

4. NEPEX and Maine responsible for plants, Sateliites for office complexes. 
Implement a voltage reduction of five percent of normal operating voltage that is attainable within 10 minutes.

Request NYPP to arrange to have NPCC Areas provide (Note 3) emergency energy to NEPOOL.

Actions 14 and 15 will normally be implemented by Iso New England through the Satellites based on advance projections made by Iso New England that it will be necessary to implement Actions 1 through 13, and that it will not be possible to maintain adequate 10-minute synchronized reserve. When Actions 14 and 15 are requested, the particular hours that they are to be implemented will be specified by ISO New England. Actions 14 and 15 should be implemented as early as possible to achieve maximum benefit.

\section{ACTION 14}

(Note 2)

Curtail Type 5-B NEPOOL Dispatchable Loads.

Request all of the customer generation not contractually available to NEPOOL Participants.

Request voluntary load curtailment by large industrial and commercial customers.

ACTION 15

(Notes 2 and 3 )

Initiate radio and television appeals for voluntary load curtailment.

Depending on the circumstances and the time required to institute certain of the above Actions, it may be necessary to call for some Actions simultaneously, or to alter the order of initiations. When all of the above Actions have been taken, further action, if required, is covered under NEPEX Operating Procedure No. 7 - Action In An Emergency (OP 7).

It may be necessary to implement NEPEX operating Procedure No. 7 - Action In An Emergency (OP 7), prior to the implementation of all of the above Actions. If, at any time during implementation of the above Actions, it appears that implementation of NEPEX Operating Procedure No. 7 will be required, Iso New England shall so notify all Satellites.

Notes: 1. A NEPEX and Maine Satellite responsibility

2. A Satellite responsibility

3. A NEPEX responsibility

4. NEPEX and Maine responsible for plants, Satellites for office complexes. 
When the system conditions have improved sufficiently, Iso New England will cancel the Actions instituted in Section A above. Depending on system conditions, the order of cancellation may be different from the order of initiation.

\section{IYPIEAIDTATION BY SATELITTES}

Any of the Actions provided in this procedure may be implemented by a satellite to deal with local conditions within that satellite. The severity of the condition will determine the degree of action taken.

D. NOTIFICATION to SATELIITES

ISo New England Control Room staff will use the "party line" telephone circuit to implement this procedure. Iso New England will briefly inform all satellites simultaneously of system conditions and issue an implementation message as illustrated below. Each Satellite, in alphabetical order, will repeat back the message to provide acknowledgement.

Typical Messages:

\section{Implementation}

- Iso New England to all Satellites: Implement NEPEX OP 4, Actions 1 and 2 at 0930.

- ISO New England to REMVEC: Implement NEPEX OP 4, Action 2 through Action 4 at 1030.

- ISO New England to all Satellites: Implement NEPEX OP 4. Action 6 at 1100 .

*Note: Where substantial lead time is required for some NEPOOL Dispatchable Loads, it will be necessary to specify the time and day/date of implementation.

\section{Cancellation}

- Iso New England to all Satellites: Cancel NEPEX OP 4, Actions 2 and 1 at 1200 .

- ISO New England to REMVEC: Cancel NEPEX OP 4, Actions 4 through 2 at 1300 .

- Iso New England to all Satellites: Cancel NEPEX OP 4, Action 6 at 1400 .

Each Satellite shall be responsible for keeping its member companies and ISO New England informed of all situations pertaining to implementation and cancellation of this procedure. Iso New England will make notifications to the Department of Energy as required by NEPEX Operating Procedure No. 10 - Power System Emergency Reporting Procedures (OP 10). 
The Satellites will make notifications to state regulatory agencies as required. Iso New England will issue a report to the appropriate NEPOOL Committee(s) following implementation of this procedure.

E. IMPLEMENTATION OF AN ALERT

Iso New England Control Room staff will notify, as appropriate, the Maine Satellite and the generation stations as soon as OP4 conditions are anticipated or underway by executing its responsibilities as declared by MASTER/SATELLITE PROCEDURE NO. 2 (ABNORMAL CONDITIONS ALERT)

Op-4-spt.doc wrb-9/13/96 
Estimates of Additional Generation and Load Relief from System-Wide Implementation of Actions in Operating Procedure No. 4 (OP 4) - Action During a Capacity Deficiency Based on a 21,000 MW System Load

(Actual MW available may be greater or less than indicated values depending on system conditions and the circumstances of the implementation)

\begin{tabular}{|c|c|c|}
\hline Action 1 & Description & Megawatts \\
\hline 1 & $\begin{array}{l}\text { Steam Generation to Maximum Claimed } \\
\text { Capability }\end{array}$ & 115 \\
\hline 2 & ICU Generation to Maximum Claimed Capability & 45 \\
\hline 3 & $\begin{array}{c}\text { Curtail Type } 2 \text { NEPOOL Dispatchable Loads - } \\
\text { Block E }\end{array}$ & 0 \\
\hline 4 & $\begin{array}{c}\text { Curtail Type } 2 \text { NEPOOL Dispatchable Loads - } \\
\text { Block D }\end{array}$ & 0 \\
\hline 5 & $\begin{array}{c}\text { Curtail Type } 2 \text { NEPOOL Dispatchable Loads - } \\
\text { Block C }\end{array}$ & 20 \\
\hline 6 & $\begin{array}{c}\text { Purchase Emergency Capacity and/or Energy } \\
\text { from Neighboring Systems }\end{array}$ & $\begin{array}{l}\text { Variable, depending on System Conditions } \\
\text { (Could be between } 500 \text { to } 1,000 \text { ) }\end{array}$ \\
\hline 7 & $\begin{array}{c}\text { Curtail Typo } 2 \text { NEPOOL Dispatchable Loads - } \\
\text { Block B }\end{array}$ & 125 \\
\hline 8 & $\begin{array}{c}\text { Curtail Type } 2 \text { NEPOOL Dispatchable Loads - } \\
\text { Block A }\end{array}$ & 95 \\
\hline 9 & $\begin{array}{c}\text { Voluntary Load Curtailment of NEPOOL } \\
\text { Participants' Facilities }\end{array}$ & 40 \\
\hline \multirow[t]{3}{*}{10} & $\begin{array}{c}\text { Customer Generation Contractually Available to } \\
\text { NEPOOL Participants During a Capacity } \\
\text { Deficiency } \\
\end{array}$ & 40 \\
\hline & Curtail Type 5 NEPOOL Dispatchable Loads & 60 \\
\hline & Total Action 10 & 100 \\
\hline 11 & Allow 30-Minute Reserve to go to Zero & $\begin{array}{l}\text { About } 575 \text { MW, depending on NEPOOL 2nd } \\
\text { contingency }\end{array}$ \\
\hline \multirow[t]{3}{*}{12} & $\begin{array}{l}\text { Implementation of } 5 \% \text { Voltage Reduction } \\
\text { Requiring More than } 10 \text { Minutes }\end{array}$ & 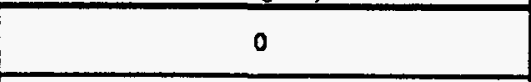 \\
\hline & $\begin{array}{c}\text { At this point the NEPOOL ten-minute reserve } \\
\text { will be allowed to diminish and subsequernt } \\
\text { Actions will be taken to maintain an absolute } \\
\text { minimum required level. }\end{array}$ & $\begin{array}{l}\text { Aboul } 1000 \mathrm{MW} \text {, depending on system } \\
\text { conditions and circumstances and on NEPOOL's } \\
\text { largest contingency. }\end{array}$ \\
\hline & Total Action 12 & 1.000 \\
\hline 13 & $\begin{array}{c}\text { Implementation of } 5 \% \text { Voltage Reduction } \\
\text { Requiring } 10 \text { Minutes or Less } \\
\end{array}$ & $450(1)$ \\
\hline \multirow[t]{3}{*}{14} & $\begin{array}{l}\text { Customer Generation Not Contractually } \\
\text { Available to NEPOOL Participants } \\
\end{array}$ & 45 \\
\hline & $\begin{array}{l}\text { Voluntary Load Curtailment by Large Industrial } \\
\text { and Commercial Customers }\end{array}$ & $190(2)$ \\
\hline & Total Action 14 & 235 \\
\hline 15 & $\begin{array}{c}\text { Radio and TV Appeais for Voluntary Load } \\
\text { Curtailment }\end{array}$ & 200 \\
\hline & Total & $3500-4000$ \\
\hline
\end{tabular}

(1) Includes 8 MW above MCC on Bridgeport Harbor 3 that may be available by switching from buming coal to buming oil and 15 MW above MCC that may be available on various PSNH generators.

(2) The actual load relief obtainable is highly dependent on circumstances surrounding the appeals, including timing and the amount of advanced notice that can be given. 


\section{APPENDIX B:}

\section{ISO New England}

Operating Procedure No. 7

Action in an Emergency 


\section{NEPEX OPERATING PROCEDURE NO. 7 \\ ACTION IN AN EMERGENCY}

APPROVED: BY the NEPOOL Interim Operations Committee to be effective December 12, 1969

REVISED: April 22, 1971

July 21, 1972

May 27, 1976

August 24, 1978

July 1, 1994

April 24, 1997 Effective with SPORT Implementation May 30, 1997

Sept. 15, 1997 This revision incorporates the April 24, 1997 and May 30, 1997 versions and is effective with the implementation of SPORT.

REFERENCE: 1. NPCC Emergency Operation Criteria A3

2. NERC Guide III - Emergency Operations

3. NEPOOL CRS NO.19 - Transmission Operations

4. NEPEX Operating Procedure No.6 - System Restoration

SATELIITE INSTRUCTION NO.

CONVEX: $\quad$ Operating Instruction No.7

MAINE: $\quad$ MAINE Operating Procedure No.7

NEW HAMPSHIRE: PSNH Operating Procedure No.7

REMVEC: $\quad$ REMVEC Operating Procedure No.7 - Action

During An Emergency 


\section{INTRODUCTION}

This document establishes procedures to be followed in the event of an operating emergency involving unusually low

Erequency, eguipment overload or unacceptable voltage levels in an isolated or widespread area of New England. The objectives in establishing these emergency procedures are:

1. To minimize the effect on customer service

2. To restore the balance between customers' load and available generation in the shortest practicable time

3. To minimize the risk of damage to transmission and generating equipment, to distribution equipment and to customers' equipment

\section{RESPONSIBILITY}

I. IsO New England Responsibility

ISO New England has the responsibility and authority to direct the actions that may be required for the implementation of this procedure, such as load shedding or opening of circuits, when the emergency situation involves:

A. An overall capacity deficiency in New England or in any area within New England

B. New England's interconnections with adjacent Control Areas/systems.

c. Conditions on facilities external to New England caused by operations or conditions in New England

D. Transmission and/or generating facilities within New England.

\section{Satellite Responsibility}

The satellites have the responsibility and authority to direct the actions that may be required for the implementation of this procedure when the emergency condition involves:

A. A capacity deficiency in an area wholly within one 
Satellite

B. The transmission and/or generating facilities under the operating jurisdiction of a single satellite.

C. The risk of damage to equipment under the operating jurisdiction of a single satellite when accompanied by a loss of communications with ISO New England

\section{PROCEDURE}

I. Preparation For Implementation

Normally, the potential need for emergency actions prescribed by this procedure should be determined well in advance of the time the actions must be implemented. This procedure may be implemented either before, during, or after action taken under NEPEX Operating Procedure No. 4 - Action During A Capacity Deficiency depending on the circumstances of the emergency.

When system conditions indicate that implementation of this procedure may be required, ISO New England and the Satellites will establish and, if appropriate, maintain continuous communication in preparation for a ISO New England directive to implement the procedure. Prompt action may provide time to be more selective in the application of this procedure.

If any Satellite and ISO New England are unable to establish prompt communication, the Satellite will proceed to implement the procedure independently.

When time and circumstances allow, ISO New England and the Satellites shall discuss the emergency conditions and reach consensus on the actions to be taken and the timing of those actions.

When operating circumstances do not allow time for consensus decisions, ISO New England and/or the Satellite will initiate the necessary actions prescribed by this procedure with the understanding that actions resulting in the higher level of reliability will be taken.

\section{Procedures for Low Frequency Conditions}

In an emergency characterized by a frequency drop, identification of the deficient Area or Areas is vital to expedite corrective action. The ISO New England Control Room 
Staff shall establish communications with other interconnected Areas to determine, if possible, the cause of the frequency decline and the action required to restore frequency to $60.00 \mathrm{~Hz}$.

A. When the cause of the declining frequency is outside of New England:

Confirm existing interchange schedules with adjacent NPCC Areas.

Regulate the New England ties to maintain the frequency-biased interchange schedules.

Increase the amount of synchronized reserve to be able to adjust the interchange schedule further, if needed.

The ISO New England Control Room Staff shall make known to external Areas the amount of emergency capacity NEPOOL can make available.

B. When the cause of the declining frequency is due to a deficiency in New England:

Confirm existing interchange schedules with adjacent NPCC Areas.

The ISO New England Control Room Staff shall request assistance from external Areas up to the emergency transfer limit of the interconnection tie lines.

When the frequency reaches $59.90 \mathrm{~Hz}$ :

Disconnect any pumped storage units operating in the pumping mode. They will be automatically disconnected at $59.65 \mathrm{~Hz}$.

Order all fast-start nonsynchronized units into service.

When the frequency reaches $59.80 \mathrm{~Hz}$ :

Automatic Generation Control (AGC) will be tripped automatically

Direct all thermal generation to Reserve Claimed Capability at maximum response rates. 
When the frequency reaches $59.30 \mathrm{~Hz}$ :

Underfrequency relays will provide 108 load relief. By the time the frequency reaches 59.00 $\mathrm{Hz}$, confirm that this relief was provided (Appendix A, Emergency Condition A) .

When the frequency reaches $58.80 \mathrm{~Hz}$ :

Underfrequency relays will provide an additional $15 \%$ load relief. By the time frequency reaches $58.50 \mathrm{~Hz}$, confirm that this relief was provided. (Appendix A, Emergency Condition B)

If the load shedding by automatic underfrequency relays does not stabilize the frequency and it continues to decline below $58.50 \mathrm{~Hz}$

Order manual load shedding in accord with Appendix $B$ to the extent necessary to restore frequency to $60.00 \mathrm{~Hz}$

$50 \%$ of New England's load, including the $25 \%$ that is shed automatically, can be shed manually. Details of the manual load shedding procedure and statements to be used by operators are included in Appendix C.

All stations shall take the necessary action, including separating units from the system, to preserve generation and minimize damage and service interruptions.

III. Procedures for a Transmission Emergency

Operation of the transmission system under emergency conditions shall be governed by the NEPEX Criteria, Rules, and Standard No. 19 - Transmission Operation (CRS 19). Emergency Actions, including the switching of transmission elements, implementing voltage reductions, and the shedding of firm load, can be taken by ISO New England and the Satellites to maintain reliability.

Pool Operators and Satellites operators are responsible to keep appropriate Supervisors at ISO New England and the Satellites advised as to conditions that might necessitate management review of the need to implement Emergency Actions on a pre-contingency basis. 
IV. Procedures for Unacceptable Voltage Conditions

NEPEX Operating Procedure No. 12 - Voltage and Reactive Control (OP 12) and various voltage guides define criteria and establish guides for action to be taken to insure that desirable levels of voltage are maintained on the transmission system. The Satellite Control Center shall make every effort to correct unacceptable voltage and shall coordinate actions with ISO New England.

When unacceptable voltage conditions occur and corrective actions described in NEPEX OP 12 and/or the voltage guides are not effective, the ISO New England Control Room Staff and/or the Satellite operators should take Emergency Actions, as defined in CRS 19, to correct the situation.

Pool operators and Satellites operators are responsible to keep appropriate Supervisors at ISO New England and the Satellites advised as to conditions that might necessitate management review of the need to implement Emergency Actions on a pre-contingency basis.

V. Restoration of Load

ISO New England will direct the restoration of any load shed under this procedure when system conditions permit.

OP7.

$4 / 24 / 97$ 


\section{AUTOMATIC - LOAD SHEDDING SCERDULE}

BASED ON A IEPEX PEAR LOAD OF 21,400 MEGAWATTS

SYSTEM

NEPEX

CONVEX

MAINE

NEW HAMPSHIRE

REMVEC
$1,500 \mathrm{MW}$

$1,300 \mathrm{MW}$

$11,550 \mathrm{MW}$

EMERGENCY PEAR LOAD*

$21,400 \mathrm{MW}$

$7,050 \mathrm{MW}$

1,500 MH

$1.300 \mathrm{MW}$

$11,550 \mathrm{MH}$

B
PERCENT LOAD

TO BE SHED

10

15

10

15

10

15

A 10

B 15

130

195

$\begin{array}{ll}\text { A } & 10 \\ \text { B } & 15\end{array}$
2, 140

3,210

705

1,058

150

225

APPROX. MW OE

LOAD TO BE SHED

Note: $\quad$ Each Satellite and-Participant is expected to establish automatic load shedding procedures based on peak-load percentages which will result in approximately the figures shown for each satellite. It is understood that figures can vary from Participant to Participant.

* Values rounded to the nearest $50 \mathrm{MN}$.

OP7APPA.

6/05/97 


\section{APPENDIX B}

MANUAL LOAD SHEDDING SCHEDULE

BASED ON NEPEX PEAK LOAD OF 21,400 MEGAWATTS STEP NO. AND APPROXIMATE MEGAWATTS OF LOAD TO BE SHED

\begin{tabular}{|c|c|c|c|c|c|c|c|}
\hline STEP\# & $\begin{array}{c}\text { NEPEX } \\
21,400 \text { MW }\end{array}$ & $\begin{array}{c}\text { CONVEX } \\
7,050 \text { MW }\end{array}$ & $\begin{array}{l}\text { MAINE } \\
1,500 \mathrm{MW}\end{array}$ & $\begin{array}{l}\text { NEW } \\
\text { HAMPSHIRE } \\
1,300 \mathrm{MW}\end{array}$ & $\begin{array}{c}\text { REMVEC } \\
11,550 \text { MW }\end{array}$ & $\begin{array}{l}\text { NEPEX } \\
21,400 \quad M W\end{array}$ & STEP\# \\
\hline 1 & 214 & 70 & 15 & 13 & 116 & 214 & 1 \\
\hline 2 & 428 & 140 & 30 & 26 & 232 & 428 & 2 \\
\hline 3 & 642 & 210 & 45 & 39 & 348 & 642 & 3 \\
\hline 4 & 856 & 280 & 60 & 52 & 464 & 856 & 4 \\
\hline 5 & 1,070 & 350 & 75 & 65 & 580 & 1,070 & 5 \\
\hline 6 & 1,284 & 420 & 90 & 78 & 696 & 1,284 & 6 \\
\hline 7 & 1,498 & 490 & 105 & 91 & 812 & 1,498 & 7 \\
\hline 8 & 1,712 & 560 & 120 & 104 & 928 & 1,712 & 8 \\
\hline$\dot{9}$ & 1,926 & 630 & 135 & 117 & 1,044 & 1,926 & 9 \\
\hline 10 & 2,140 & 700 & 150 & 130 & 1,160 & 2,140 & 10 \\
\hline 15 & 3,210 & 1,050 & 225 & 195 & 1,740 & 3,210 & 15 \\
\hline $20^{\circ}$ & 4.280 & 1,400 & 300 & 260 & 2,320 & 4,280 & 20 \\
\hline 25 & 5,350 & 1,750 & 375 & 325 & 2,900 & 5,350 & 25 \\
\hline $30^{\prime}$ & 6,420 & 2,100 & 450 & 390 & 3,480 & 6,420 & 30 \\
\hline 35 & 7.490 & 2,450 & 525 & 455 & 4,060 & 7.490 & 35 \\
\hline $40^{3}$ & 8,560 & 2,800 & 600 & 520 & 4,640 & 8,560 & 40 \\
\hline 48 & 9,630 & 3,150 & 675 & 585 & 5,220 & 9,630 & 45 \\
\hline $50^{\circ}$ & 20,700 & 3,500 & 750 & 650 & 5,800 & 10,700 & 50 \\
\hline
\end{tabular}

Note: Each participant 1s expected to develop a manual load shedding plan which will result in shedding 50 t of load on peak. The step numbers shown in this table correspond to an equivalent percent and assume all satellites peak coincidentally with NEPEX, which may or may not be true. Insofar as Satellite and Participant loads conform to the NEPEX load, an " $X$ " percent load change in NEPEX will regult in the same percent change for the Satellite or participant. clearly, all loads do not conform to the NEpex loads. Therefore, the table is approximate only. 


\section{INSTRUCTIONS FOR INPLEMELTIATION OF MANUAL IOAD SHEDDINGG}

The following instructions are to be observed by the NEPEX POol Coordinators during the manual shedding of load. These instructions are to be used in conjunction with Appendix A which specifies the step number of the load shedding procedure.

I. WERM SHEDDITKG LOAD NEPES WIDE:

A. Communication With Satellites

All Satellites will be on the line prior to the time the Pool Coordinator issues instructions.

\section{B. Quantity of Load}

The Pool Coordinator will direct the quantity of load to be shed or restored by specifying a step number.

Step Number $=$ Total MW Load to be Shed or Restored $\times 100$ Instantaneous NEPEX Load

C. Instruction Messages

Issue concise verbal instructions and await Satellite acknowledgment which should be received from all satellites alphabetically. Typical messages for the Pool coordinators and System Operators are:

Implementation:

a. NEPEX TO AIL: Implement OP 7 - Manually shed load from step through step

b. NEPEX TO ALL: Implement OP 7 - Manually restore load from step through step 
Acknowledqment:

a. OP 7 - Manually shed load from step through step

b. OP 7 - Manually restore load from step through step

D. Examples: Typical Implementation and Acknowledgment Messaces

1. a. NEPEX LOad - $21,400 \mathrm{MW}$

b. NEED - Shed 500 MW uniformly throughout New England.

c. Messages:

Implementation: $\quad 50,000 \div 21,400=2.3$

NOTE: To achieve $500 \mathrm{MW}$ within Appendix B load shedding schedule, the fractional step result must be rounded down or up to the next step value.

NEPEX TO ALI: Impletnent OP 7 - Manually shed load from step 1 through step 3

Acknowledoment:

CONVEX: OP 7 - Manually shed load from step I through step 3

MAINE: OP 7 - Manually shed load from step I through step 3

N.H.: $\quad$ OP 7 - Manually shed load from step 1 through step 3

REMVEC: OP 7 - Manually shed load from step 1 through step 3

2. a. NEPEX Load $=20,900 \mathrm{MW}$

b. NEED: - Restore 500 MW of load that had been previously shed uniformly throughout New England.

c. Messages:

Implementation: $\quad 50,000 \div 20,900=2.4$ 
NOTE: To achieve $500 \mathrm{MW}$ within Appendix B Ioad shedding schedule, the fractional step result must be rounded down or up to the next step value.

NEPEX TO ALL: Implement OP 7 - Manually restore load from step 3 through step 1

Acknowledgment:

CONVEX: OP 7 - Manually restore load from step 3 through step 1

(Other satelites respond in alphabetical order)

II. WBIFN SEBSDING LOAD IN INDIVIDUAC SATELIITE(S)

A. Communication With Satellite(s)

The affected Satellite(s) will be contacted individually and instructions will be issued by the Pool coordinator. The unaffected satellites will then be contacted individually and informed of the situation.

\section{B. Quantity of Load}

The Pool Coordinator will direct the quantity of load to be shed or restored by specifying a step number.

Step Number $=$ Total MW Load to be Shed or Restored $\times 100$ Instantaneous Load of Applicable Satellite (s)

NOTE: Applicable Satellites are those within the area in which load shedding will be effective in alleviating a problem.

\section{Instruction Messages}

Issue concise verbal instructions and await satellite acknowledgment. Typical messages for the pool- Coordinators and System Operators are: 
Implementation:

a. NEPEX TO ___: Implement OP 7 - Manually shed load from step through step

b. NEPEX TO : Implement OP 7 - Manually restore load from step through step

Acknowledgment:

a. , OP 7 - Manually shed load from step through step

b. , OP 7 - Manually restore load from step through step

D. Examples: Troical Implementation and Acknowledgment Messages

1. a. NEPEX Load - 21,400 MW CONVEX - 7,050 MW

b. NEED - Shed $200 \mathrm{MW}$ of load in CONVEX.

C. Messages

Implementation: $20,000 \div 7,050=3$

NOTE: To achieve $200 \mathrm{MW}$ within Appendix B load shedding schedule, the fractional step result must be rounded down or up to the next step value.

NEPEX TO CONVEX: Implement OP 7 - Manually shed load from step 1 through step 3

Acknowledoment:

CONVEX: OP 7 - Manually shed load from step 1 through step 3

E. Notification Messages

Unaffected Satellites will be notified by the Pool coordinator after specific satellites bave been instructed to implement OP 7. A typical notification and message for pool Coordinators and System Operators is: 
Implementation:

NEPEX To (Unaffected Satellites)

This is a notification that OP 7 is being implemented in CONVEX. CONVEX has been instructed to manually shed/restore load from step through step

Acknowledgment:

(Unaffected Satellites), OP 7 notification.

CONVEX to manually shed/restore load from step through step

III. WEEN SHEDDING LOAD IN A SPECIFIC AREA WITHIN A SATELIITE

A. Communications With Satelites

The affected Satellite will be contacted individually and instructions will be issued by the Pool coordinator. The unaffected Satellites will then be contacted individually and informed of the situation.

B. Quantity and Location of Load

The pool Coordinator will direct the quantity and location of load to be shed or restored by specifying a step number and the specific area affected.

Step Number $=\frac{\text { Total MW Load to be Shed or Restored } \times 100}{\text { Instantaneous Load of Applicable Area }}$

Note: Applicable area is that predefined area in which post contingency load shedding is the only method remaining to maintain first contingency coverage. 
C. Instruction Messages

Issue concise verbal instructions and await Satellite acknowledgment. Typical messages for the Pool Coordinators and System Operators are:

\section{Implementation:}

a. NEPEX TO : Implement OP 7. Manually shed load from step through step in the area.

b. NEPEX TO : Implement $O P 7$ 7. Manually restore load from step through step in the area.

Acknowledoment:

a.

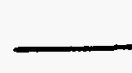
, through step in the area.

b. OP 7 - Manually restore load from step through step in the area.

D. Examples: Typical Implementation and Acknowledoment Messages

1. a. NEPEX Load - $21,400 \mathrm{MW}$

CONVEX - 7,050 MW

SOUTRWEST CONNECTICUT LOAD - 3,525 MW

b. NEED - Shed 200 MW of load in Southwest Connecticut.

c. Messages

Implementation: $\quad 20,000 \div 3,525=6$

NOTE: To achieve 200 w within Appendix B load shedding schedule, the fractional step result must be rounded down or up to the next step value.

NEPEX TO CONVEX: Implement OP 7 - Manually shed load from step 1 through step 6 in the Southwest Connecticut Area 
Acknowledgment:

CONVEX: OP 7 - Manually shed load from step 1 through step 6 in the Southwest Connecticut Area

E. Notification Messages

Unaffected Satellites will be notified individually by the pool Coordinator after a specific Satellite has been instructed to implement $O P$ in a particular area. A typical notification message for Pool Coordinators and System Operators is:

Implementation:

NEPEX To (Unaffected Satellites)

This is a notification that $O P 7$ is being implemented in the Southwest Connecticut Area of CONVEX. CONVEX has been instructed to manually shed/restore load from step through step in the Soutbwest Connecticut Area.

Acknowledgment:

(Onaffected Satellites) OP 7 notification.

CONVEX to manually shed/restore load from step through step in the Southwest Connecticut Area.

OP7APPC.

$6 / 05 / 97$ 


\section{APPENDIX C:}

Generating Capacity

Added Through the

1997 Summer Generating Resources Program 
The following $503 \mathrm{MW}$ of additional generating capability was brought on line in 1997 as a result of ISO New England's 1997 Summer Generating Resources Program:

Reactivation of generating units

Unit Name

MW

Bridgeport Harbor

Indeck Jonesboro and W. Enfield

Mason 3,4, and 5

Nantucket

West Springfield 1 and 2

Worchester Energy

TOTAL

Upgrading selected generating units to increase their capability

Unit Name

MW

Canal 2

Devon 11-14

Manchester Street 9-11

Ocean State Power

South Meadow 15

TOTAL

Leasing temporary mobile generators or purchasing from $E W G$

Unit Name

MW

CPC Lowell

Groton Navy Yard Units

TOTAL 


\section{APPENDIX D:}

\section{Load Profile}

\section{for New England and Connecticut}

Summer 1998 


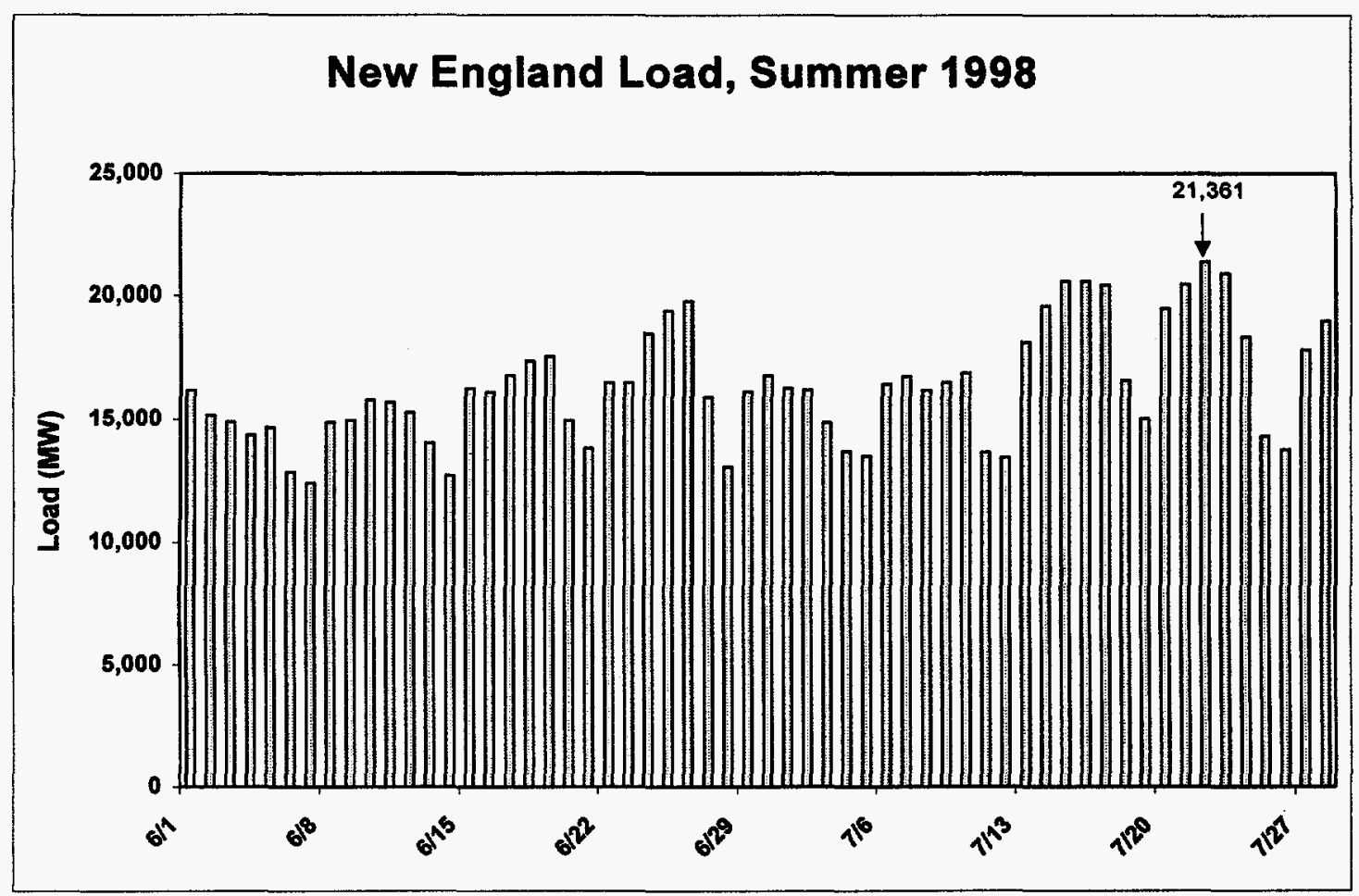

Source: CONVEX Capacity Analysis, CONVEX web site (www.cvx.com), July 29, 1998.

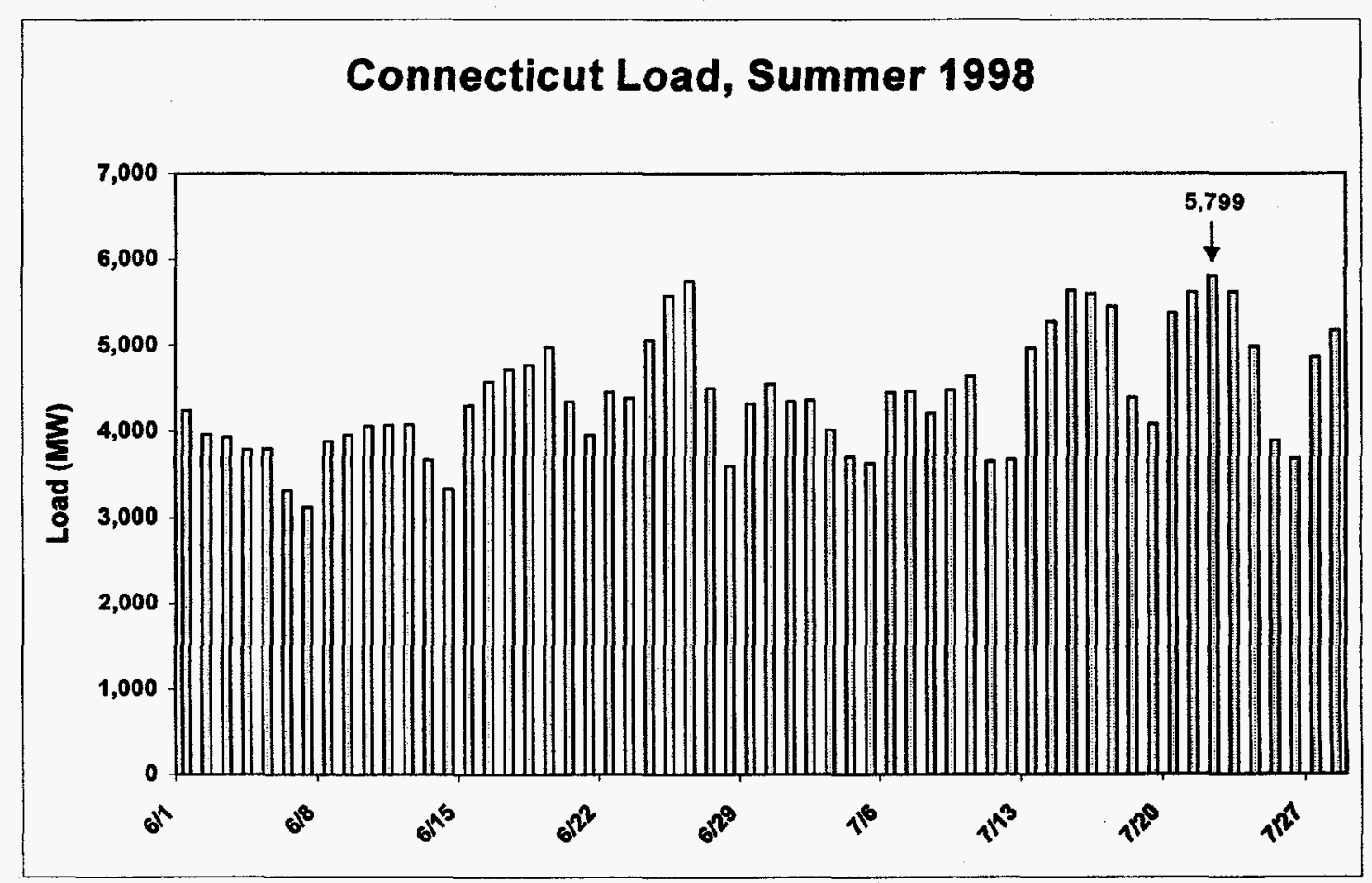

Source: CONVEX Capacity Analysis, CONVEX web site (www.cvx.com), July 29, 1998. 
APPENDIX E:

\section{ISO New England}

Interconnection Study Status

for Proposed and Planned

Transmission and Generation Projects 
ISO New England Interconnection Study Status ${ }^{1}$

Proposed/Planned Interconnection (and Long Term Firm Point-to-Point Transmission Service)

\begin{tabular}{|c|c|c|c|c|c|c|}
\hline $\begin{array}{c}\text { Date of } \\
\text { Completed } \\
\text { Application }\end{array}$ & Project & MW & $\begin{array}{c}\text { Project } \\
\text { In- } \\
\text { Service } \\
\text { Date } \\
\end{array}$ & Location & $\begin{array}{c}\text { Study } \\
\text { Complete }\end{array}$ & $\begin{array}{c}\text { Study } \\
\text { Report } \\
\text { Available } \\
\text { From } \\
\end{array}$ \\
\hline $6 / 7 / 96^{*}$ & $\begin{array}{l}\text { Millennium - } \\
\text { USGen }\end{array}$ & 400 & 2000 & Charlton, MA & yes & $\begin{array}{l}\text { New } \\
\text { England } \\
\text { Power Co. }\end{array}$ \\
\hline $11 / 8 / 96^{*}$ & EMI Tiverton & 265 & 2000 & Tiverton, RI & yes & $\begin{array}{l}\text { Eastern } \\
\text { Utilities } \\
\text { Associates }\end{array}$ \\
\hline $2 / 13 / 97^{*}$ & $\begin{array}{l}\text { Androscoggin } \\
\text { Energy Center }\end{array}$ & 157 & 1998 & Jay, ME & yes & $\begin{array}{l}\text { Central } \\
\text { Maine } \\
\text { Power }\end{array}$ \\
\hline $4 / 10 / 97^{*}$ & EMI Dighton & 185 & 2000 & Dighton, MA & yes & $\begin{array}{l}\text { Eastern } \\
\text { Utilities } \\
\text { Associates }\end{array}$ \\
\hline $5 / 9 / 97^{*}$ & Brayton Pt. 5 & 477 & 2001 & $\begin{array}{l}\text { Swansea, } \\
\text { MA }\end{array}$ & & \\
\hline $6 / 12 / 97^{\star}$ & $\begin{array}{l}\text { EMI Rumford } \\
\text { Power Assoc. }\end{array}$ & 265 & 2000 & Rumford, ME & yes & $\begin{array}{l}\text { Central } \\
\text { Maine } \\
\text { Power }\end{array}$ \\
\hline $6 / 25 / 97^{*}$ & $\begin{array}{l}\text { Bridgeport } \\
\text { Harbor } 340 / 520 \\
\text { MW }\end{array}$ & 520 & $98 / 99$ & $\begin{array}{l}\text { Bridgeport } \\
\text { Harbor, CT }\end{array}$ & $\begin{array}{l}\text { yes (340 } \\
\text { MW) }\end{array}$ & $\begin{array}{l}\text { United } \\
\text { Illuminating }\end{array}$ \\
\hline $7 / 15 / 97^{*}$ & ANP Blackstone & 580 & 2000 & $\begin{array}{l}\text { Blackstone, } \\
\text { MA }\end{array}$ & yes & $\begin{array}{l}\text { New } \\
\text { England } \\
\text { Power Co. }\end{array}$ \\
\hline $7 / 15 / 97^{*}$ & ANP Bellingham & 580 & 2000 & $\begin{array}{l}\text { Bellingham, } \\
\text { MA }\end{array}$ & yes & $\begin{array}{l}\text { New } \\
\text { England } \\
\text { Power Co. }\end{array}$ \\
\hline $7 / 22 / 97$ & $\begin{array}{l}\text { IDC Bellingham } \\
3 \text { @ } 345 \mathrm{MW}\end{array}$ & 1035 & $2001 / 02$ & $\begin{array}{l}\text { Bellingham, } \\
\text { MA }\end{array}$ & & \\
\hline $7 / 24 / 97$ & $\begin{array}{l}\text { ME } \\
\text { Independence }\end{array}$ & 500 & 2000 & Graham, ME & & \\
\hline
\end{tabular}

1 Source: ISO New England website (www.iso-ne.com). The information contained in this table was last updated by ISO New England on 6/25/98. 


\begin{tabular}{|c|c|c|c|c|c|c|}
\hline $\begin{array}{c}\text { Date of } \\
\text { Completed } \\
\text { Application }\end{array}$ & Project & MW & $\begin{array}{l}\text { Project } \\
\text { In- } \\
\text { Service } \\
\text { Date }\end{array}$ & Location & $\begin{array}{l}\text { Study } \\
\text { Complete }\end{array}$ & $\begin{array}{c}\text { Study } \\
\text { Report } \\
\text { Available } \\
\text { From } \\
\end{array}$ \\
\hline $8 / 5 / 97$ & $\begin{array}{l}\text { EMI Wareham } \\
\text { Power }\end{array}$ & & withdrawn & Tremont, MA & & \\
\hline $8 / 15 / 97$ & Berkshire Power & 276 & 1999 & Agawam, MA & & \\
\hline $8 / 22 / 97$ & $\begin{array}{l}\text { Devon (BP } \\
\text { Development) }\end{array}$ & 540 & 2000 & Milford, CT & & \\
\hline $8 / 22 / 97$ & $\begin{array}{l}\text { Summit Power } \\
\text { (BP } \\
\text { Development) }\end{array}$ & 276 & 2001 & $\begin{array}{l}\text { Westfield, } \\
\text { MA }\end{array}$ & & \\
\hline $9 / 30 / 97$ & Cabot Power & 350 & 2000 & Everett, MA & & \\
\hline $10 / 9 / 97$ & $\begin{array}{l}\text { S. Norwalk } \\
\text { Power Project }\end{array}$ & 175 & 2000 & $\begin{array}{l}\text { S. Norwalk, } \\
\text { CT }\end{array}$ & & \\
\hline $10 / 24 / 97$ & ANP Gorham & 850 & 2000 & Portland, ME & & \\
\hline $12 / 12 / 97$ & $\begin{array}{l}\text { Lake Road - } \\
\text { USGen }\end{array}$ & 810 & 2001 & Killingly, CT & & \\
\hline $12 / 12 / 97$ & SEl Newington & 560 & 2000 & $\begin{array}{l}\text { Newington, } \\
\mathrm{NH}\end{array}$ & & \\
\hline $1 / 13 / 98$ & $\begin{array}{l}\text { Versaille Energy } \\
\text { Center }\end{array}$ & 240 & 2000 & Versaille, CT & & \\
\hline $1 / 13 / 98$ & $\begin{array}{l}\text { White Mt. Cogen } \\
\text { Center }\end{array}$ & 90 & 2000 & $\begin{array}{l}\text { Groveton, } \\
\mathrm{NH}\end{array}$ & & \\
\hline $1 / 13 / 98$ & $\begin{array}{l}\text { Piscataqua } \\
\text { Power }\end{array}$ & 700 & 2000 & $\begin{array}{l}\text { Newington, } \\
\mathrm{NH}\end{array}$ & & \\
\hline $1 / 14 / 98$ & $\begin{array}{l}\text { Livermore Falls } \\
\text { Energy }\end{array}$ & 40 & 2000 & $\begin{array}{l}\text { Livermore } \\
\text { Falls, ME }\end{array}$ & & \\
\hline $1 / 20 / 98$ & $\begin{array}{l}\text { Housatonic } \\
\text { Power }\end{array}$ & 700 & 2001 & Sherman, CT & & \\
\hline $2 / 11 / 98$ & $\begin{array}{l}\text { Wallingford } \\
\text { Power }\end{array}$ & 550 & $2000 / 01$ & $\begin{array}{l}\text { Wallingford, } \\
\text { CT }\end{array}$ & & \\
\hline $2 / 11 / 98$ & $\begin{array}{l}\text { AES } \\
\text { Londonderry }\end{array}$ & 720 & 2001 & $\begin{array}{l}\text { Londonderry, } \\
\mathrm{NH}\end{array}$ & & \\
\hline $2 / 16 / 98$ & Meriden Power & 544 & 2001 & Meriden, CT & & \\
\hline $2 / 19 / 98$ & $\begin{array}{l}\text { HQ-Surowiec, } \\
\text { CMP HVDC }\end{array}$ & 600 & 2002 & Pownal, ME & & \\
\hline $2 / 27 / 98$ & Patriot Power & 520 & 2001 & Taunton, MA & & \\
\hline
\end{tabular}




\begin{tabular}{|c|c|c|c|c|c|c|}
\hline $\begin{array}{c}\text { Date of } \\
\text { Completed } \\
\text { Application }\end{array}$ & Project & MW & $\begin{array}{c}\text { Project } \\
\text { In- } \\
\text { Service } \\
\text { Date } \\
\end{array}$ & Location & $\begin{array}{l}\text { Study } \\
\text { Complete }\end{array}$ & $\begin{array}{c}\text { Study } \\
\text { Report } \\
\text { Available } \\
\text { From } \\
\end{array}$ \\
\hline $3 / 6 / 98$ & $\begin{array}{l}\text { S\&P } \\
\text { Cogeneration } \\
\text { Facility }\end{array}$ & & withdrawn & Lynn, MA & & \\
\hline $3 / 13 / 98$ & AES Carpenter & 700 & 2001 & $\begin{array}{l}\text { Southington, } \\
\text { CT }\end{array}$ & & \\
\hline $3 / 18 / 98$ & $\begin{array}{l}\text { Newington } \\
\text { Energy Center }\end{array}$ & 520 & 2001 & $\begin{array}{l}\text { Newington, } \\
\mathrm{NH}\end{array}$ & & \\
\hline $3 / 25 / 98$ & $\begin{array}{l}\text { Norwich Power } \\
\text { Station }\end{array}$ & 500 & 2000 & Norwich, CT & & \\
\hline $3 / 25 / 98$ & $\begin{array}{l}\text { Engage Energy } \\
\text { LT Firm PtP In }\end{array}$ & 300 & 2000 & $\begin{array}{l}\text { NB-MEPCO } \\
\text { border }\end{array}$ & & \\
\hline $3 / 26 / 98$ & $\begin{array}{l}\text { Tuspani Power } \\
\text { Company }\end{array}$ & 750 & $2000 / 01$ & $\begin{array}{l}\text { North } \\
\text { Smithfield, RI }\end{array}$ & & \\
\hline $3 / 30 / 98$ & Towantic Energy & 540 & $2001 / 02$ & Oxford, CT & & \\
\hline $3 / 31 / 98$ & $\begin{array}{l}\text { Mystic Power } \\
\text { Station (Sithe) }\end{array}$ & 1750 & 2001 & $\begin{array}{l}\text { Charlestown, } \\
\text { MA }\end{array}$ & & \\
\hline $3 / 31 / 98$ & $\begin{array}{l}\text { Edgar Power } \\
\text { Station (Sithe) }\end{array}$ & 1500 & 2001 & $\begin{array}{l}\text { Weymouth, } \\
\text { MA }\end{array}$ & & \\
\hline $3 / 31 / 98$ & $\begin{array}{l}\text { Medway Power } \\
\text { Station (Sithe) }\end{array}$ & 1500 & 2001 & $\begin{array}{l}\text { West } \\
\text { Medway, MA }\end{array}$ & & \\
\hline $3 / 31 / 98$ & $\begin{array}{l}\text { Framingham } \\
\text { Power } \\
\text { Station (Sithe) }\end{array}$ & 750 & 2001 & $\begin{array}{l}\text { Framingham, } \\
\text { MA }\end{array}$ & & \\
\hline $3 / 31 / 98$ & $\begin{array}{l}\text { Westbrook } \\
\text { Power }\end{array}$ & 520 & 2000 & $\begin{array}{l}\text { Westbrook, } \\
\text { ME }\end{array}$ & & \\
\hline $4 / 1 / 98$ & WEG-Norwich & 500 & 2001 & Nonwich, CT & & \\
\hline $4 / 2 / 98$ & Wyman A & 550 & 2000 & $\begin{array}{l}\text { Yarmouth, } \\
\text { ME }\end{array}$ & & \\
\hline $4 / 2 / 98$ & Wyman B & 550 & 2000 & $\begin{array}{l}\text { Yarmouth, } \\
\text { ME }\end{array}$ & & \\
\hline $4 / 2 / 98$ & Mason & 550 & 2000 & $\begin{array}{l}\text { Wiscasset, } \\
\text { ME }\end{array}$ & & \\
\hline $4 / 14 / 98$ & $\begin{array}{l}\text { FPL - ESI New } \\
\text { Bedford }\end{array}$ & 250 & 2000 & $\begin{array}{l}\text { New } \\
\text { Bedford, } \\
\text { MA }\end{array}$ & & \\
\hline
\end{tabular}




\begin{tabular}{|c|c|c|c|c|c|c|}
\hline $\begin{array}{c}\text { Date of } \\
\text { Completed } \\
\text { Application }\end{array}$ & Project & MW & $\begin{array}{c}\text { Project } \\
\text { In- } \\
\text { Service } \\
\text { Date }\end{array}$ & Location & $\begin{array}{c}\text { Study } \\
\text { Complete }\end{array}$ & $\begin{array}{c}\text { Study } \\
\text { Report } \\
\text { Available } \\
\text { From }\end{array}$ \\
\hline 4/16/98 & $\begin{array}{l}\text { Bucksport } \\
\text { Energy }\end{array}$ & 174 & 1999 & $\begin{array}{l}\text { Bucksport, } \\
\text { ME }\end{array}$ & & \\
\hline $4 / 29 / 98$ & R.I. Hope Energy & 500 & 2001 & Johnston, RI & & \\
\hline $5 / 8 / 98$ & $\begin{array}{l}\text { Rocky River } \\
\text { Power }\end{array}$ & 530 & 2001 & $\begin{array}{l}\text { New Milford, } \\
\text { CT }\end{array}$ & & \\
\hline $5 / 28 / 98$ & $\begin{array}{l}\text { HQ-Highgate } 2 \\
\text { HVDC }\end{array}$ & 600 & 2001 & Highgate, VT & & \\
\hline $5 / 28 / 98$ & $\begin{array}{l}\text { CVPS/GMP LT } \\
\text { Firm PtP In }\end{array}$ & 600 & 2002 & $\begin{array}{l}\text { NY-VT } \\
\text { border }\end{array}$ & & \\
\hline $6 / 1 / 98$ & $\begin{array}{l}\text { Glen Charlie } \\
\text { Unit } 1\end{array}$ & 500 & 2001 & $\begin{array}{l}\text { Wareham, } \\
\text { MA }\end{array}$ & & \\
\hline $6 / 4 / 98$ & Canal Unit 3 & 561 & 2001 & $\begin{array}{l}\text { Sandwich, } \\
\text { MA }\end{array}$ & & \\
\hline 6/8/98 & $\begin{array}{l}\text { Tractebel LT } \\
\text { Firm } \\
\text { PtP In }\end{array}$ & 300 & 2002 & NB-NEPOOL & & \\
\hline $\begin{array}{l}\text { [Application } \\
\text { Pending] }\end{array}$ & $\begin{array}{l}\text { Orrington } \\
\text { Generation } \\
\text { Project }\end{array}$ & 700 & 2001 & $\begin{array}{l}\text { Orrington, } \\
\text { ME }\end{array}$ & & \\
\hline & TOTAL & 29,700 & & & & \\
\hline
\end{tabular}

1. Note: The exact dates of application completion are preliminary and are still under review; however, the project order is not expected to change following final date verification. Dates marked with an asterisk $\left(^{*}\right)$ are dates of study agreement. 